\title{
Mutual fund flight-to-liquidity ${ }^{1}$
}

\author{
February 2016
}

\begin{abstract}
This paper examines the liquidity choices of mutual funds during times of market uncertainty. I find that when markets are uncertain, mutual funds actively increase the liquidity of their portfolio - often referred to as a 'flight-to-liquidity.' In aggregate, mutual fund behaviour has implications for the market; the market driven flight-toliquidity places upward pressure on the liquidity premium. I examine the underlying mechanisms driving fund behaviour. I show that market volatility is associated with lower fund performance and withdrawals, which causes funds to adjust the composition of their portfolio towards more liquid assets in order to meet potential redemptions. This causal chain is consistent with Vayanos (2004), who argues that fund managers are investors with time-varying liquidity preferences due to threat of withdrawal. Aggregated over funds, the effect is substantial: a one standard deviation increase in my measure of flight-to-liquidity yields a 0.63 standard deviation increase in the excess return required for holding illiquid securities.
\end{abstract}

Keywords: Market uncertainty, financial crisis, liquidity, flight-to-liquidity, mutual funds, institutional investors, price pressure, idiosyncratic volatility, systematic risk

JEL classification: G01, G11, G12, G14, G20

\footnotetext{
${ }^{1}$ I thank Susan Christoffersen, Wayne Ferson, Søren Hvidkjær, Markku Kaustia, Lasse Heje Pedersen, Jesper Rangvid, Ben Sand, Mike Simutin, Morten Sørensen for helpful comments and suggestions. I am also grateful to participants at the PhD Nordic Finance Workshop in Helsinki, 3rd Annual USC Marshall Ph.D. Conference in Finance and brown bag seminar at Copenhagen Business School.
} 
"Crises feed uncertainty. And uncertainty affects behaviour, which feeds the crisis." - Oliver Blanchard. ${ }^{2}$

A stock's liquidity and how its liquidity evolves over time are a primary concern to investors. Recent studies show that investors prefer more liquid stocks and expect an extra compensation for holding an illiquid asset (Amihud and Mendelson (1986), Brennan and Subrahmanyam (1996), Amihud (2002)). Similarly, market makers need compensation for providing liquidity to investors and they charge a higher price if a traded asset is less liquid. This excess return required by both investors and market makers for bearing liquidity risk, which is called the liquidity premium, not only varies over time (Acharya and Pedersen (2005), Pástor and Stambaugh (2003), or Hagströmer, Hansson, and Nilsson (2013)), but it is also correlated to measures of market uncertainty. However, the mechanism driving this association is not well understood:

The fact that expected returns from liquidity provision are strongly related to the VIX index does not necessarily imply that the VIX index itself is the state variable driving expected returns from liquidity provision. More likely, the VIX proxies for the underlying state variables that drive the willingness of market makers to provide liquidity and the public's demand for liquidity. (Nagel (2012), p.2008)

In this paper, I investigate one channel through which market uncertainty affects the liquidity premium. Whereas Nagel (2012) relates the price of liquidity to its supply, I explore a demandside explanation. In particular, I argue that times of high uncertainty coincide with large market declines. Consequently, retail investors have greater demands for liquidity and this places upward pressure on the liquidity premium. ${ }^{3}$ While I cannot directly observe an investor's demand for liquidity, it can be partly inferred from mutual funds' net flows. This is due to the fact that mutual funds provide liquidity to their shareholders . Consistent with this idea, I show that uncertainty is associated with greater outflows from mutual funds. Mutual funds, responding to the greater threat of redemptions during times of uncertainty, shift the composition of their portfolios toward more liquid assets - the so called 'flight-to-liquidity.' As funds respond to an aggregate market condition, the coordination of their behaviour places downward price pressure on illiquid assets. The effect is substantial: a one standard deviation in my measure of flight-to-liquidity causes a 0.63 standard deviation increase in the market price of liquidity.

\footnotetext{
${ }^{2}$ The Economist, Jan 29th 2009.

${ }^{3}$ See e.g. Bernardo and Welch (2004) and Morris and Shin (2004).

${ }^{4} \mathrm{~A}$ related and recent paper by Huang (2015) provides empirical evidence of an association between expected market volatility and the liquidity of mutual fund holdings. My paper builds on this evidence by exploring the underlying mechanism driving this association and relating mutual fund liquidity management to the market level price of liquidity.
} 
In order to examine the link between market uncertainty and the price of liquidity, I draw on insight from Vayanos (2004). In his model, investors withdraw their money if a fund performs poorly, which is more likely during times of high market uncertainty. Consequently, redemption obligations increase when markets are volatile and fund managers put the value of flexibility before its cost by adjusting portfolios toward liquid assets. Market uncertainty induces an aggregate shift in mutual fund demand for liquidity, which feedbacks into the market price for liquidity and generates time-variation in the liquidity premium. My empirical analysis exploits the structure suggested by Vayanos (2004) to examine this causal chain.

I investigate a mutual fund's response to uncertainty with US open-ended mutual funds data from Morningstar. In these data mutual funds actively invest in US equity between January 1998 and December 2013. A key variable in my analysis, which I refer to as 'active liquidity management,' is a measure of how funds actively manage the liquidity of their portfolios by adjusting the composition of their assets. I construct this variable by first computing a fund's monthly portfolio liquidity as a weighted average of the holdings Amihud's (2002) liquidity measure, where the weights are a fraction of the portfolio invested in each stock. The change in a fund's portfolio liquidity between two months can be decomposed via a common shift-share analysis. ${ }^{5}$ This decomposition represents a shift in portfolio liquidity from two distinct sources: (1) shifts due to a change in the liquidity of the holdings (the Amihud measure), and (2) shifts due to active modification of a portfolio's composition in terms of holdings. This second component is my measure of a fund's active liquidity management, since it isolates the change in a portfolio's liquidity directly under the fund manager's control.

In Vayanos's (2004) model, a key factor impacting a fund's liquidity preference is the threat of withdrawal, which is increasing in market volatility. Thus, a key relationship in my analysis is how a fund's active liquidity management responds to net flows, which I examine in a regression framework. In doing so, I attempt to control for possible confounding factors, such as variables that capture overall market performance and the availability of liquidity, seasonality and year fixedeffects, and also for a complete, unrestricted set of fund-level fixed effects. These latter variables are meant to capture possible time-invariant fund characteristics. Using this set of controls, I identify the effect of net flows on liquidity management by focusing on within-fund and within-year, overtime variation. The OLS estimates of this relationship suggest that funds are unresponsive to net flows. However, while fund fixed effects mitigate the problem of possible correlation between net flows and fund time-invariant factors, there is still a potential endogeneity concern arising from omitted time-varying variables that are correlated with fund flows, such as time-varying skills (Kacperczyk, van Nieuwerburgh, and Veldkamp (2014)). To overcome this potential identification issue, and to focus on variation in net flows stemming from market uncertainty, I exploit the structure of Vayanos's model which suggests a natural instrumental variable - market volatility.

\footnotetext{
${ }^{5}$ Shift-share allows to decompose the change in a weighted mean into one part that is due to a chnage in the weights and another part that is due to the change in the underlying variable (Dunn 1960).
} 
A two-stage estimation procedure arises naturally from the structure of the model, which predicts that net flows are negatively impacted by market uncertainty, causing funds to adjust portfolio liquidity. The first-stage relates net flows to market uncertainty, which is measured in my baseline empirical work by a realized market volatility estimator, and controls for the same variables as above. I find that realized volatility strongly predicts outflows from equity mutual funds, a necessary requirement for the instrumental variables estimation procedure. This result is both consistent with the model and with existing literature. ${ }^{6}$ In the first-stage regression, a one standard deviation shock to market volatility decreases aggregate fund flows by $0.4 \%$. Following Vayanos's (2004) framework, I show that this effect is partly explained by a deterioration in a fund's performance when markets are more volatile.

The second-stage relates a fund's active liquidity management to variation in net flows induced by market uncertainty. In contrast to the OLS estimates, I find that by isolating the variation in fund net flows stemming only from market volatility, mutual funds strongly respond to redemption obligations by actively managing the liquidity of their portfolio. A one standard deviation decrease in fund's net flows causes a 1.9 standard deviation increase in actively managed portfolio's liquidity. This estimate is robust to market-wide returns and liquidity, and focuses on within-year variation. Thus, the identifying variation comes from shifts in realized market volatility holding market-wide performance and liquidity constant. In order for the instrumental variables procedure to yield causal estimates of mutual fund responses to uncertainty, my maintained assumption is that these shifts in realized volatility, above and beyond a rigorous set of controls for market performance, are exogenous to mutual funds. While this assumption is plausible, since individual funds are small relative to the market as a whole, I also show that the results are robust to using variation in realized volatility that is not forcastable by US CBOE Volatility Index (VIX), which I call a 'volatility shock.' This robustness check ensures that my results are not driven by anticipatory behaviour.

These results demonstrate that mutual funds respond to negative shocks to their flows induced by market uncertainty by increasing the liquidity of their portfolios. In aggregate, the time-varying liquidity preferences of mutual funds can contribute to the time-varying nature of the market price of liquidity (Vayanos (2004)). To examine this link, I measure the market liquidity premium as the additive inverse of the difference between illiquid and liquid portfolio returns, following Jensen and Moorman (2010). I relate this to mutual fund demand for liquidity, which I calculate by aggregating my measure of active liquidity management over funds in each period. The association between these two variables is strong and is consistent with the model's predictions. In order to address any endogeneity concern inherent in the analysis of the prices on quantities, I use market volatility in an instrumental variable approach. By only using the variation in aggregate active liquidity management stemming from market uncertainty, I show that a volatility-induced shift in

\footnotetext{
${ }^{6}$ For example, Ederington and Golubeva (2011) and Ferson and Kim (2012) show a negative relationship between future expected volatility and net aggregate equity fund flows.
} 
preferences towards more liquid assets exerts downward price pressure on illiquid stocks, which is reflected in the narrowing of the measured return spread. A one standard deviation increase in actively managed portfolio's liquidity decreases the return spread by $2.13 \%$. Thus, a major contribution of my paper is that it provides a partial explanation for the observed relationship between the liquidity premium and market uncertainty found in the literature.

In my baseline analysis I use only equity holdings information to study a mutual fund's response to the threat of withdrawal. In reality, cash is an important component of a fund active liquidity management. Thus, I incorporate information on cash holdings into my analysis. First, I treat a cash holdings decision separately from liquidity management of equity holdings. I show that fund managers increase the percentage of the portfolio held in cash when they face the threat of redemptions, consistent with Huang (2015). However, treating cash and equity decisions separately is incorrect if there is strategic interaction between those two decisions. I respond to this difficulty by incorporating both cash and equity into a fund's portfolio by treating cash as any other equity position when measuring active liquidity management. The novelty of my approach is that it allows for the analysis of the joint decisions regarding cash and equity asset liquidity. I assign the Amihud measure of zero to cash and use weights equal to the fraction of a portfolio held in the form of cash. After incorporating cash into a fund's active liquidity management, I show that the response to uncertainty remains unchanged.

One potential weakness of my analysis is that it relies on over-time variation that is common to all funds. However, funds differ from one another in terms of the composition of their holdings. This difference will translate into differences in exposure to market volatility, which is measured as the volatility of the $\mathrm{S} \& \mathrm{P} 500$. In order to assess the importance of this, I create a fund-specific volatility measure that is based on the composition of assets the funds actually hold. For each mutual fund, I measure the fraction of the portfolio invested in one of the ten GICS sectors, and construct a fund-specific uncertainty measure by estimating the value-weighted average of Garman and Klass's (1980) sector realized volatility. This method allows both over-time and between-fund variation to be exploited in my analysis. I find that mutual funds react stronger to my fund-specific volatility measure compared to the market one. This implies that my results based on market volatility are conservative, since fund reaction depends on their portfolio exposure. This result is new to the literature.

A possible source of heterogeneity of a fund's response to market uncertainty comes from the differences in its initial liquidity position. Funds that happen to be more illiquid when market volatility increases are expected to have stronger reactions since it is more difficult for them to meet redemptions. To investigate this, I develop a measure of 'illiquidity shock' for each fund. This variable is defined as a percentage change in a portfolio's liquidity due to a change in the market-wide Amihud measure of the assets, holding investment shares fixed. The idea behind this variable is that it captures shocks to a fund's liquidity position that are exogenous to management decisions at a specific date. In fact, this measure arises naturally in my shift-share decomposition of a fund's average Amihud changes. I show that mutual funds actively manage the liquidity of 
their portfolio not only in times of high market uncertainty, but also when they face an illiquidity shock. This finding suggests that managers target the liquidity of their portfolio. While this result is consistent with the theoretical predictions of Ang, Papanikolaou, and Westerfield (2014), empirically establishing evidence of a liquidity targeting in the case of mutual funds is a new contribution to the literature. I also show that mutual funds experiencing an illiquidity shock respond stronger to market uncertainty, meaning that they more aggressively tilt their portfolio towards liquid stocks.

My paper contributes to the literature along a number of dimensions. My primary contribution is to show that aggregate mutual fund active liquidity management, driven by market volatility, influences the market price of liquidity. Underlying this finding at the aggregate level, I show a strong and robust response of mutual funds to market volatility that uncovers the fundamental mechanisms driving this aggregate response. First, I establish that market uncertainty is associated with lower fund performance and withdrawals. Second, in response to the threat of withdrawals, funds actively rebalance their portfolios toward more liquid assets. This finding is stronger when (1) funds are in an initially weak liquidity position, and (2) when funds have greater exposure to uncertainty, as captured by the fund-specific volatility measure that I develop. I establish that these findings are robust to incorporation of cash to analyse the joint decisions regarding cash and equity asset liquidity, and to using variation driven by market volatility that is not forcastable.

A number of studies are related to this work. First, as noted above, my empirical work is guided by the theoretical model of Vayanos (2004). The empirical focus of my work is related to Huang (2015) and Ben-Rephael (2014). However, in contrast to these papers, which estimate reduced form relationships, I provide a mechanism explaining mutual fund flight-to-liquidity by more formally investigating Vayanos (2004), and relate fund responses to the market price of liquidity. Ben-Rephael (2014)'s identification comes from times of crisis, whereas my paper's identification is general, and comes from within-year shifts in market volatility. Thus, I show that flow-induced changes in mutual fund liquidity preferences are reflected in the time-varying market price of liquidity more generally, and are not just isolated to times of crisis. I use market uncertainty as the main driver of mutual fund flight-to-liquidity. Beber, Brandt, and Kavajecz (2009) also condition their analysis on market uncertainty and they show a shift in liquidity preferences of sovereign bond investors when market volatility is high. I show that market volatility affects mutual fund demand for liquidity, which is in line with the prediction of Brunnermeier and Pedersen (2009) that increases in market volatility coincide with liquidity dry-ups. Whereas my study investigates the impact of the threat of withdrawals on mutual fund active liquidity management, Liu and Mello (2011) analyse optimal asset allocation for hedge funds in the face of possible coordinated redemptions. There is also a series of papers examining the effect of mutual fund flows on concurrent stock returns. However, none of these explain the time-varying nature of liquidity premium with flowinduced trading. Lou (2012) shows that flow-induced trading can explain stock price momentum. Greenwood and Thesmar (2011) relates price volatility and the co-movement in stock returns to the trades of distressed mutual fund and their spill-over effects. Coval and Stafford (2007) demonstrate that flow-induced transactions of funds experiencing substantial in- and outflows exert price 
pressure on their traded holdings, thus providing liquidity to those constrained funds can be very profitable.

The paper is organized as follows. In the next section, I relate my analysis to the existing literature. In section 2, I describe the data and the variable construction in detail. In Section 3, I explain estimation approach and report the empirical results. In Section 4, I show the robustness of my results. Section 5 concludes.

\section{Related Literature}

This paper is related to, and builds on, three distinct lines of literature. First, my paper contributes to a large and growing literature that focuses on liquidity dry-ups with evidence of a causal mechanism related to investor behaviour. The second contribution of the paper lies in an examining investor's portfolio liquidity choices, which is related to a literature that began with the seminal paper of Constantinides (1986). Finally, my paper adds to the literature discussing the asset pricing implications of investor behaviour.

\subsection{Liquidity Dry-Ups}

My study relates to the growing literature on times of liquidity dry-ups. Much of the literature discusses the mechanism leading to periods of evaporating liquidity. For example, Bernardo and Welch (2004) model liquidity runs, where investors fear future liquidity shocks and prefer to sell today in order to receive an average price. Brunnermeier and Pedersen (2009) provide a model with a feedback relationship between assets' market liquidity and investors' funding liquidity. They predict that increases in market volatility coincide with drops in market liquidity, because of marketmakers' limited liquidity provision. Malherbe (2014) proposes an adverse selection liquidity model, where holding cash imposes a negative externality, reducing future market liquidity and causing liquidity dry-ups. ${ }^{7}$

There is little empirical evidence on investors' behaviour in times of liquidity crises. Beber et al. (2009) focus on the importance of the quality and the liquidity for the determination of sovereign yield spreads. They show changes in a credit quality can explain sovereign yield spreads to a large extent. However, in times of market uncertainty liquidity of sovereign bonds is the main driver of the yield spreads. ${ }^{8}$ My study builds on this existing literature by analysing liquidity preferences of equity mutual funds in times of high market volatility, which in turn coincide with liquidity dry-up periods.

\footnotetext{
${ }^{7}$ See also Gennotte and Leland (1990), Huang and Wang (2009), and Krishnamurthy (2010).

${ }^{8}$ See also Longstaff (2004).
} 


\subsection{Portfolio Choices with Trading Costs}

Several theoretical studies investigate investors' portfolio choices in the presence of trading costs. Ang et al. (2014) propose a model of an optimal allocation between liquid and illiquid assets. The liquidity risk comes from periods of an uncertain duration, where illiquid assets cannot be traded and consumption can only be funded by a liquid part of the portfolio. They show, among others, that investors have an optimal portfolio composition of liquid and illiquid assets $\left(\xi^{*}\right)$, to which they rebalance whenever it is possible. The portfolio management in times of crisis constitutes the main focus of a growing number of empirical studies. Manconi, Massa, and Yasuda (2012) look at institutional bond holders in 2007. They find that liquidity-constrained mutual funds contribute to the transmission of the crises from securitized bonds to corporate bonds. Huang (2015) shows in a reduced form that mutual funds have liquidity preferences in times of market uncertainty and their liquidity management is reflected in fund performance. Ben-Rephael (2014) analyses ten episodes of volatility shocks. He shows that mutual funds on average sell more illiquid than liquid stocks and illiquid assets experience a greater price discount than liquid ones during crisis periods.

My empirical study is closely related to the model of Vayanos (2004). In the theoretical framework, he proposes a link between volatility-induced performance and net flows that, in turn, affect a fund's behaviour. The probability of fund performance falling below a benchmark increases with volatility. Fund investors monitor the performance and they withdraw their money when the performance drops below the threshold. Since mutual fund managers fear the redemptions, they require higher risk premium per unit of volatility and are less willing to keep illiquid stocks in their portfolio. In consequence, illiquid stocks experience greater price discount what is reflected in an increase in market liquidity premium. The threat of the redemptions is also a main driver of an institutional investor portfolio allocation in the study of Liu and Mello (2011). They propose a model on portfolio choices of hedge funds up against the risk of coordinated withdrawals. There is a trade-off between higher returns and greater liquidation costs that determines an optimal level of cash holdings. However, hedge fund managers choose a suboptimal (too high) level of cash as a result of their fear of coordinated redemptions. ${ }^{9}$ My empirical analysis focuses on equity mutual fund portfolio composition in face of a threat of withdrawal. Consistent with the existing literature, I show that mutual fund managers target the liquidity of their portfolio and in face of threat of withdrawals they shift towards more liquid assets.

\subsection{Asset Pricing Implications of Funds' Behaviour}

This paper shows a relationship between volatility induced fund active asset allocation and market liquidity premium. Thus, my analysis also relates to the literature that focuses on an

\footnotetext{
${ }^{9}$ Chernenko and Sunderam (2015) show that cash holdings play a significant role in accommodation of mutual fund in- and outflows.
} 
explanation of market predictabilities with mutual fund trading which is induced by investors' flows and managers correlated behaviour. Coval and Stafford (2007) provides a rational explanation for the deviation of stock prices from its fundamental value. They show that mutual fund transactions triggered by both large out- and inflows can push prices away from their intrinsic value. Investors trading against those distress funds can generate a high return from providing liquidity. Lou (2012) explains the return momentum and reversal by means of expected flow-induced trading. ${ }^{10}$ Finally, Gârleanu and Pedersen (2007) develop a theoretical framework, where they link market liquidity and risk-management practices of institutional investors. They show that in case of high market volatility, or reduced risk-bearing capacity a feedback relationship between risk-management and market liquidity can arise. As a result of tighter risk-management the prices of illiquid stocks decrease and the market price of liquidity increases. My empirical analysis provides evidence that stock prices can deviate from their intrinsic value because of investor demand unrelated to the fundamentals. In line with the existing literature, I show that mutual fund transactions induced by the threat of withdrawal put upward price pressure on the liquidity premium.

\section{Data and Variable Construction}

In this section, I introduce my data source and processing procedures. I also explain the construction of the variables used for my analysis and I discuss descriptive statistics.

\subsection{Mutual fund and stock data}

I use monthly mutual fund holdings obtained from Morningstar database for the period of 1998-2013. The data is complied from both mandatory SEC filings and voluntary disclosures. Elton, Gruber, Blake, Krasny, and Ozelge (2010) provide a comparison of the Morningstar holdings data with the more frequently used data from Thomson Reuters. They conclude that Morningstar is without survivorship bias and it captures $18.5 \%$ more trades than Thomson Reuters database does. Since this paper focuses on the impact of mutual fund active asset allocation on the US equity market, I include domestic mutual funds actively investing in US equity.

Mutual funds' total net assets (TNA), net returns, net flows, cash holdings and other fund characteristics are also obtained from Morningstar database. For mutual funds with multiple share classes, I calculate the TNA-weighted average of net returns (cash holdings) across all share classes to derive the net return (cash holdings) of the fund. Mutual fund net flows are already available at the fund level.

The stock data (daily returns, prices, trading volumes and shares outstanding) for common

\footnotetext{
${ }^{10}$ See for return comovement - Anton and Polk (2014) and Greenwood and Thesmar (2011), liquidity comovement - Koch, Ruenzi, and Starks (2012).
} 
shares (share code 10 and 11) are obtained from the Center for Research in Security Prices (CRSP). I require each stock to have at least 15 days of return and dollar volume data in a month. I use CUSIP identification number to merge mutual fund holdings information with CRSP stock database. I include only those mutual funds with $70 \%$ of their holdings value identified as a common US equity and successfully merged with CRSP dataset. In order to measure market uncertainty, I obtain daily information on open, close, high, and low price for S\&P 500 index from Finance Yahoo website, and daily VIX observation from Chicago Board Options Exchange (CBOE). ${ }^{11}$

After applying these screening procedures, I obtain a sample of 85,560 fund-month observations on 1,601 different mutual funds. Table 1 shows summary statistics of the mutual funds' main characteristics for each year. The number of mutual funds in the sample increases from 169 in 1998 to 1,006 in 2013. The median TNA varies over time between 252.05 million in 2003 and 765.16 million in 1998. The number of different stocks held across all mutual funds in my sample increases from 2,285 in 1998 to 3,908 in 2007. There is some skewness in the number of stocks held by mutual funds, meaning that there are few mutual funds with numerous stocks in their portfolio. The median number of stocks per fund is between 64 and 90. The last column in Table 1 shows the percentage of the holdings value that has been successfully merged with common stocks from CRSP dataset.

\subsection{Variable construction}

\subsubsection{Illiquidity measure}

A stock's liquidity is unobservable. Out of many liquidity proxies I choose Amihud's (2002) measure. ${ }^{12}$ Following Amihud (2002), I define the illiquidity of a stock $s$ on the day $d$ as:

$$
\text { Illiq }_{s, d}=\frac{\left|R_{s, d}\right|}{V_{s, d}}
$$

where $R_{s, d}$ is stock $s$ return on day $d$ and $V_{s, d}$ is its dollar volume. I use monthly frequency of mutual fund holdings, thus I estimate monthly stock liquidity by averaging Amihud's (2002) daily measure in month $t$ :

$$
\operatorname{Illiq}_{s, t}=\sqrt{\frac{1}{D_{s, t}} \sum_{d=1}^{D_{s, t}} \operatorname{Illiq}_{s, d}}
$$

\footnotetext{
${ }^{11}$ https://ca.finance.yahoo.com/q/hp?s=^GSPC and http://www.cboe.com/micro/vix/historical.aspx.

${ }^{12}$ Hasbrouck (2009) shows that out of liquidity measures, which he tested, square-root transformation of Amihud measure is the most strongly correlated liquidity proxy with TAQ-based price impact coefficient.
} 
where $D_{s, t}$ is the number of observation for stock $s$ in month $t$. To reduce the influence of extreme observations, I choose a square-root transformation. ${ }^{13}$ I use a stock-level liquidity measure to compute a monthly value-weighted illiquidity measure at the mutual fund level:

$$
I l l i q_{f, t}=\sum_{s=1}^{S_{f, t}} \omega_{f, t}^{s} \cdot I l l i q_{s, t},
$$

where $S_{f, t}$ is the number of stocks held by mutual fund $f$ in the month $t$, and $\omega_{f, t}^{s}$ is a fraction of the portfolio of fund $f$ in month $t$ held in stock $s$.

Existing studies show that market volatility affects a stock's liquidity (e.g. Chung and Chuwonganant (2014), Brunnermeier and Pedersen (2009)). ${ }^{14}$ Furthermore, the liquidity of a fund's portfolio can change between two months for two reason: its holdings become more or less liquid, and a fund manager actively manages liquidity of the portfolio by trading securities. In order to separate these two effects I perform a shift-share analysis by decomposing the change in portfolio's liquidity into two components. The first component captures shifts due to a change in the liquidity of the holdings (Amihud measure), and the second corresponds to shifts in the active modification of a portfolio's composition in terms of holdings. I decompose the change in a fund's portfolio liquidity in the following way:

$$
\begin{aligned}
\Delta \operatorname{Illiq}_{f, t} & =\sum_{s=1}^{S_{f, t}} \omega_{f, t}^{s} \cdot \operatorname{Illiq}_{s, t}-\sum_{s=1}^{S_{f, t-1}} \omega_{f, t-1}^{s} \cdot \operatorname{Illi} q_{s, t-1} \\
& =\sum_{s=1}^{S_{f, t-1}} \omega_{f, t-1}^{s}\left(\operatorname{Illiq}_{s, t}-\operatorname{Illi} q_{s, t-1}\right)+\sum_{s=1}^{S_{f, t}} \operatorname{Illi} q_{s, t}\left(\omega_{f, t}^{s}-\omega_{f, t-1}^{s}\right) .
\end{aligned}
$$

The first term denotes the change in a portfolio's liquidity due to a market-wide change in individual stock's Amihud measure. The second term is my measure of a fund's active liquidity management $B_{t}^{f}$, which is obtained by isolating the component of the change in a portfolio's liquidity directly under the fund manager's control. It reflects the change in the value of holdings composition as a consequence of asset purchases and sales actively performed by fund's manager.

One challenge with the data is to disentangle an investor's demand for liquidity from her demand for quality. Beber et al. (2009) show that investors' demand for safety and liquidity at

\footnotetext{
${ }^{13}$ I use the square-root transformation, because it enables me to include cash holdings into the behaviour measure in the later part of my analysis. My results are robust to other Amihud measure transformations. Chordia, Huh, and Subrahmanyam (2009), Hasbrouck (2009), and Chen, Goldstein, and Jiang (2010), among othres, use the square-root tranformation of Amihud measure as well.

${ }^{14}$ Chung and Chuwonganant (2014) shows that the liquidity of a single stock is strongly related both to its own risk and to the level of uncertainty in the market as a whole. In their theoretical model, Brunnermeier and Pedersen (2009) also predict that increases in VIX coincide with drops in market liquidity, because market-maker's liquidity provision is limited when the market volatility is high.
} 
the bond market changes over time. In times of market distress investors chase liquidity rather than credit quality. I use a stock's quality measure constructed by Asness, Frazzini, and Pedersen (2013) to control for a portfolio's quality. ${ }^{15}$ The quality measure captures four dimensions of quality: profitability, growth, safety, and pay. For each mutual fund every month, I calculate a value-weighted quality rank Quality $f_{t}^{f}$ (eq. 3) and use it as a fund level control variable.

\subsubsection{Fund performance and investors flows}

In Vayanos's (2004) model, an investor withdrawals from a mutual fund, when a fund's performance falls below a given threshold. As the threshold is not precisely defined, I use the S\&P 500 index as the benchmark. The S\&P 500 index seems to be a natural choice, as even daily newspapers deliver information about its performance on a regular basis. I define mutual fund $f$ performance in month $t$ as:

$$
\operatorname{Perf}_{f, t}=R_{f, t}-R_{M, t},
$$

where $R_{f, t}$ is mutual fund monthly return net of management, administrative, and $12 \mathrm{~b}-1$ fees and $R_{M, t}$ is the return on $\mathrm{S} \& \mathrm{P} 500$ index in month $t$.

Morningstar provides estimated fund-level net flows (MFlow ${ }_{t}^{f}$ ) at the monthly frequency. ${ }^{16} \mathrm{I}$ compute the relative net flows in order to capture the percentage of money flowing into and out of a mutual fund relative to its total assets:

$$
\text { Flow }_{f, t}=\frac{\text { MFlow }_{f, t}}{T N A_{f, t-1}}
$$

where $T N A_{f, t-1}$ is a total net asset of the fund $f$ in the previous month.

\subsubsection{Market level variables}

I use historical market volatility as a proxy for uncertainty measure. Following prior literature (e.g. Longstaff, Pan, Pedersen, and Singleton (2011)), I choose a standard way of estimating realized market volatility proposed by Garman and Klass (1980). The Garman-Klass volatility estimator can be calculated based on open-high-low-close prices (OHLC) of the S\&P 500 index:

$$
R \operatorname{Vol}_{t}=\sqrt{\frac{Z}{D_{t}} \cdot \sum_{d=1}^{D_{t}} \frac{1}{2} \cdot\left(\log \frac{h_{d}}{l_{d}}\right)^{2}-(2 \cdot \log (2)-1) \cdot\left(\log \frac{c_{d}}{o_{d}}\right)^{2}},
$$

\footnotetext{
${ }^{15}$ I am grateful to Lasse Heje Pedersen for sharing with me their quality measure.

${ }^{16}$ An estimated fund-level net flows are computed from aggregated share-class-based flows if available, otherwise estimated from surveyed fund size.
} 
where $h_{d}, l_{d}, o_{d}$, and $c_{d}$ are high, low, open, and close prices of stock S\&P 500 index on day $d$. $Z$ is the number of closing prices in a year, and $D_{t}$ is the number of historical prices used for the market volatility estimate in month $t$.

In the robust analysis, I use a non-forecastable part of market realized volatility. I obtain it by regressing realized market volatility measure $R V{ } l_{t}$ on its forecast for the current month. I save the residuals $\operatorname{Res}(\mathrm{Vol})_{t}$ from this regression and use them as the shock component of market volatility. I choose a monthly average of the CBOE Volatility Index (VIX) daily observations as my market volatility forecast because of its beneficial characteristic of being forward looking. ${ }^{17}$ VIX is also a well known measure for market risk and is sometimes called an 'investor fear gauge'.

Existing research shows that times of high market volatility are associated with periods of liquidity dry-ups. According to Nagel (2012), a reduction in market-wide liquidity increases the cost of providing liquidity and the risk of holding illiquid stocks. Vayanos (2004) predicts that fund managers' risk aversion increases with market uncertainty, thus they become less willing to hold illiquid securities and require a higher return for bearing the costs and risks. Consequently, illiquid stocks are especially affected by the deterioration in market liquidity and they experience sizeable price discounts. To capture time-varying liquidity premium, I use the return differential between illiquid and liquid stocks that incorporate the price movement of these securities. I construct the return spread by sorting all stocks every month into five portfolios based on their mean liquidity over past 3 months, and calculate the monthly value-weighted return for each portfolio. I create a zero-cost portfolio that is long in the least liquid quintile and short in the most liquid one. A decrease in the return on this portfolio indicates a drop in the price of illiquid securities, higher required return for holding illiquid stocks, and an increase in the market price of liquidity. ${ }^{18}$

\subsubsection{Summary statistics}

Table 2 panel A with summary statistics for the constructed variables gives some insights into mutual funds liquidity preferences. The mean (median) fund illiquidity is 31.015 (25.574), meaning that mutual funds invest in the top $12 \%$ of most liquid stocks. ${ }^{19}$ They also prefer stocks of better quality in their portfolio with the mean (median) quality rank of 0.656 (0.657). They keep on average $3.2 \%$ of their holdings in the form of cash. An average fund experiences monthly net cash flows of $0.8 \%$ of TNA and generates an average return of $0.08 \%$ above the return on the S\&P500

\footnotetext{
${ }^{17} \mathrm{CBOE}$ Volatility Index was introduced by the Chicago Board Options Exchange in 1993. It was designed to measure the market's expectation of 30-day volatility implied by at-the-money S\&P100 (VXO) option prices. In 2003, a new VIX measure was launched, which is based on the S\&P500 Index and is estimated as a weighted average of call and put prices for a wide range of strike prices (source: http://www.cboe.com/micro/vix/vixwhite.pdf).

${ }^{18}$ The return spread is an additive inverse of the proxied market liquidity premium.

${ }^{19} \mathrm{I}$ obtain the value of $12 \%$ from assigning illiquidity ranks between zero and one for all stocks every month and estimate a fund-level illiquidity rank.
} 
index.

Panel B in table 2 shows the correlations between the main variables. The market uncertainty measured by realized volatility is negatively correlated with fund relative performance (-0.22), flows $(-0.32)$, and active liquidity management measure $(-0.42)$, whereas it is positively correlated with portfolio's illiquidity (0.48). Performance is also negatively correlated with the change in marketwide liquidity $\Delta$ Noise $_{t}(-0.19)$, whilst fund flows covary positively with market return $R_{M, t}$. This strong negative relationship between realized volatility and fund performance is also pronounced in Figure 1. The shaded areas depict periods of high market volatility. This figure shows that mutual funds underperform the market in times of high market uncertainty. The negative relationship between market volatility and fund flows is illustrated in Figure 2. Not surprisingly, the plot shows that on average mutual funds experience inflows when market volatility is low, however when market uncertainty increases investors withdraw their money from equity mutual funds. ${ }^{20}$

\section{Estimation and Results}

Following Vayanos (2004), I estimate a system of three equations. He shows that high market uncertainty increases the probability of a fund's performance falling below a given threshold, which in turn, is associated with an increase in a fund's redemption obligations. Managers fear withdrawals, therefore they increase the liquidity of their portfolio and, at the same time, they exert an upward price pressure on the market liquidity premium.

\subsection{Estimation Setup}

The first step of the analysis examines whether there is a relationship between current fund performance and its flows. In Vayanos (2004), investors withdraw their money from the mutual fund if its performance falls below a given benchmark. I estimate the impact of a fund's relative performance on flows by running a regression of net flows on current performance, and a set of fundspecific and market-wide variables. I also control for fund time-invariant characteristics, seasonality in the flows, and across-year variation. ${ }^{21}$

Step 1:

$$
\text { Flow }_{f, t}=\beta_{0}+\beta_{1} \operatorname{Perf}_{f, t}+\beta_{2} Q_{f, t}+X_{t}^{\prime} \Omega+b_{f}+b_{q}+b_{y}+\epsilon_{f, t},
$$

where $Q_{f, t}$ is a measure of a quality of funds' holdings, $X_{t}$ is a vector of market-wide control variables such as return on market portfolio, market-wide liquidity, equity market liquidity, funding liquidity

\footnotetext{
${ }^{20}$ Ederington and Golubeva (2011) also find a negative correlation between equity fund flows and stock market volatility. Ferson and Kim (2012) find a negative correlation between market volatility and equity fund flows, but a positive relation between volatility and flows to bond funds and money market funds.

${ }^{21}$ See Kamstra, Kramer, Levi, and Wermers (2012) for the evidence on the seasonality in mutual fund flows.
} 
and NBER recession period dummies, $b_{f}$ is a full set of unrestricted fund fixed effects, $b_{q}$ are quarter of year specific intercepts to capture seasonal effects, and $b_{y}$ corresponds to year fixed effects. ${ }^{22}$

When analysing the impact of concurrent fund performance on its flows, a possible endogeneity problem arises. I address this with an instrumental variable approach. I use exogeneous variation in realized market volatility as an instrument. This choice of the instrument stems directly from the structure in Vayanos (2004). ${ }^{23}$ In the first stage regression I estimate the impact of market uncertainty on funds' relative performance.

First stage:

$$
\operatorname{Perf}_{f, t}=\alpha_{0}+\alpha_{1} \operatorname{RVol}_{t}+\alpha_{2} Q_{f, t}+X_{t}^{\prime} \Lambda+a_{f}+a_{q}+a_{y}+\varepsilon_{f, t} .
$$

I expect that increases in market uncertainty are associated with a deterioration in a fund's performance and outflows from equity mutual funds. My supposition is in line with existing studies of French, Schwert, and Stambaugh (1987) and Campbell and Hentschel (1992) who show that periods of high volatility are associated with downward market movements.

After showing that my first conjecture is supported by the data, I investigate whether there is a link between a fund's active liquidity management and the threat of withdrawal. I define the active liquidity management as the part of the decomposed change in the fund's illiquidity from equation (4), that is fully determined by the manager's portfolio allocation decision, $B_{f, t}$.

Step 2:

$$
B_{f, t}=\gamma_{0}+\gamma_{1} \text { Flow }_{f, t}+\gamma_{2} Q_{f, t}+X_{t}^{\prime} \Gamma+g_{f}+g_{q}+g_{y}+\xi_{f, t} .
$$

In the last step, I examine whether a mutual fund's aggregate liquidity preferences induced by market uncertainty feedback into market level of liquidity pricing and contributes to the timevarying nature of the liquidity premium. I expect that mutual funds' shift toward more liquid assets in times of high market volatility exert a downward price pressure on illiquid asset. Consequently, the measured return differential between liquid and illiquid stocks decreases and the market price of liquidity increases. To test my conjecture, I regress the return on the zero cost portfolio on the aggregate mutual fund's active liquidity management measure and other control variables. ${ }^{24}$

\footnotetext{
${ }^{22}$ I use S\&P 500 return as a proxy for market portfolio return. Hu, Pan, and Wang (2013) suggest a noise measure, which captures daily deviations of coupon-bearing Treasury securities' market yields from the model yields. They show that their measure is informative about liquidity conditions of different (market) origins. The noise data is available at: http://www.mit.edu/ junpan/Noise_Measure.xlsx. I use Pástor and Stambaugh (2003) measure for equity market liquidity from: http://faculty.chicagobooth.edu/lubos.pastor/research/liq_data_1962_2014.txt and TED spread (the difference between 3-Month LIBOR based on US dollars and 3-Month Treasury Bill) as a measure for funding liquidity from: https://research.stlouisfed.org/fred2/series/TEDRATE/downloaddata. The recession periods are taken from the NBER website: http://www.nber.org/cycles.html.

${ }^{23}$ Section 3.2 discusses the endogeneity issue more detailed.

${ }^{24}$ I sort the stocks based on their mean Amihud measure over previous three months into five portfolios. I calculate a monthly value-weighted return on each of the portfolios. The return spread $L P_{t}$ is defined as the difference between return on the least liquid portfolio and the most liquid one.
} 
Step 3:

$$
L P_{t}=\delta_{0}+\delta_{1} B_{t}+\delta_{3} Q_{t}+X_{t}^{\prime} \Theta+d_{q}+d_{y}+v_{t}
$$

where $L P_{t}$ is a return on a zero cost portfolio, which is long in illiquid stocks and short in liquid ones, $B_{t}$ denotes the aggregate measure of mutual fund's active liquidity management, computed by combining individual fund holdings information.

\subsection{Endogeneity and Instrumental Variable}

Estimation of the OLS system of equations, described in the previous sub-section, raises a potential endogeneity issue. In the first step in equation 8, simultaneity bias (reverse causation) might arise between fund performance and its flows, resulting in the correlation between fund performance and the error term $\varepsilon_{f, t}$. Thus, one of the major concerns is to consistently identify the $\alpha_{1}$ coefficient from equation 8. Most studies ignore the endogeneity issue because of the difficulty in finding plausible instruments, but exceptions include Reuter and Zitzewitz (2015) and Phillips, Pukthuanthong, and Rau (2013) who use an exogenous shock to overcome the endogeneity bias between a fund performance and flows. Following Christoffersen, Musto, and Wermers (2014), who review academic papers studying flows to asset managers, I consider several potential sources of bias. Investors come to a decision about their (dis)investment based on a fund's performance. A well performing fund attracts more capital, whereas investors withdraw their money from a bad performing one. The impact of the performance on investors flows have been studied by Ippolito (1992) and Sirri and Tufano (1998), among others. They analyse the relationship from a perspective of performance determining the flows. On the other hand, Gruber (1996) and Zheng (1999) focus on smart money effect, where fund flows can predict future performance. Christoffersen et al. (2014) also consider two other channels, through which flows influence the performance: diseconomies of scale (fund performance decreases with the fund size) and direct cost of flows (e.g. the front running costs - Coval and Stafford (2007) and incurred transaction costs reducing the average fund's performance - Edelen (1999)).

In order to estimate a fund's response to the redemption obligations, I regress a fund's active liquidity management measure on its net flows, a set of control variables and quarter of a year dummy variable to capture seasonality. By including fund fixed effects, I control for a fund's unobserved time-invariant characteristics (e.g. a fund manager talent). In order to pick up omitted shocks that affect both fund flows and liquidity management of all mutual funds (e.g. financial crises in 2008) I add a full set of unrestricted year fixed effects to the regression. However, there may still be time-varying, unobservable joint determinants of active liquidity management and net flows that are not captured by fund fixed effects. Kacperczyk et al. (2014) argue that manager's skill is not constant, but varies over time. A manager's skill come with the experience. It also depends on the focus of different tasks performed in different times. Therefore, the correlation between fund's flows and active liquidity management may wrongly indicate the causal relationship, while it is the unobservable time-varying managerial skill that determines for both fund flows and their liquidity 
preferences.

An unobservable time-varying fund's strategy can also be a potential source of endogeneity bias in equation $10 .^{25}$ Different economic conditions require different strategies of a portfolio allocation. Suppose, that a change in the strategy (towards more stock-picking one) takes place in bear times and a fund manager decreases the liquidity of the portfolio. Then, investors might demonstrate their dissatisfaction with the negative change in the strategy and withdraw their money from the fund. Thus a negative effect of fund flows on the liquidity preferences would be erroneously identified.

In the final step, I identify a response of the market liquidity premium to a shift in mutual fund liquidity preferences. Since prices and quantities are endogenously determined by demand and supply factors, the error term $v_{t}$ in equation 11 may be correlated with the measure of funds' aggregate liquidity preferences. Thus, I have to separate exogenous demand shifters in active liquidity management measure from supply ones. By isolating exogenous variation in mutual fund liquidity preferences, I can identify the impact of mutual fund demand on the market price of liquidity.

In order to address the simultaneity bias and omitted variable problem, I apply an instrumental variable approach. The choice of market uncertainty as the instrument comes naturally from the framework of Vayanos (2004) model, where he uses market volatility as a main driver of fund's performance, flows, and liquidity preferences. I exploit the fact that the realized market volatility is random from the perspective of a single mutual fund, and thus uncorrelated with the residuals in equations 8 and 10. While controlling for other variables such as market-wide liquidity measure $\Delta$ Noise $_{t}$ and funding liquidity TEDSpread ${ }_{t}$, which reflect supply-side of liquidity, I use market uncertainty as an instrument for funds' aggregate active liquidity management to identify the effect of mutual fund liquidity demand on the market price of equity in equation 11.

I estimate this system of three equations and most of subsequent specifications using panel regression model, calculating standard errors by clustering at the fund and year-month dimensions. This approach addresses the concern that the errors, conditional on independent variables, might be correlated within fund and time. Clustering only at the fund level imposes a very strong assumption that there is no cross-sectional correlation. Thus, ignoring the time effect in my panel data is incorrect and bias downwards standard errors, producing too small confidence intervals and too large t-statistics. ${ }^{26}$

\footnotetext{
${ }^{25}$ Lynch and Musto (2003) propose a model, where they show that investor flows respond to a new fund strategy.

${ }^{26}$ See Petersen (2009).
} 


\subsection{Empirical Results}

I start my empirical analysis with examining the relationship between fund flows and performance. I estimate equation 8 and report the results in Table 3, columns 4 to 6 . In each of the specifications, I include fund, quarter of year and year fixed effects. Column 4 reports results of equation 8 in a bivariate specification with fixed effects. The performance coefficient is positive and statistically significant. In column 5 , I estimate the same equation and include return on the market portfolio $R_{M, t}$, Hu et al. (2013) measure of market-wide liquidity $\Delta$ Noise $_{t}$ and Pástor and Stambaugh (2003) measure of aggregated equity market liquidity $P S_{t}$. The coefficient on fund performance remains positive and significant. Finally in column 6, I add three more control variables: a measure of funding liquidity TEDSpread ${ }_{t}$, quality of fund's holdings Quality $_{f, t}$ and a dummy variable Recession equal to one for those months that belong to NBER recession periods, otherwise zero.

The estimates of fund performance might be biased because of the reverse causality problem discussed in the previous subsection. Thus, I use the instrumental variable approach, which require a crucial assumption that the instrument is uncorrelated with the omitted variables. If this is the case, then the instrument can be used to isolate the variation in the variable of interest that is uncorrelated with the error term. I use market realized volatility as the instrument. It seems plausible, that the variation in the market volatility is non-manipulative from the perspective of a single fund. Table 3 columns 1 through 3 show the coefficients from the first stage regressions in equation 9 . The coefficient on market uncertainty remains negative and highly statistically significant in all three specification. This means that fund relative performance decreases with market uncertainty. This result is supported by the existing literature documenting a negative relationship between stock returns and market volatility (see e.g.: French et al. (1987) and Campbell and Hentschel (1992)). The magnitude of the estimated effect is economically significant. The estimated coefficient from column 1 implies that one standard deviation increase in stock market volatility decreases fund relative performance by $0.3 \%(0.21 \cdot 1.386)$. The size of the coefficient is unaffected by the inclusion of other control variables.

In table 3 columns 7 to 9 , I substitute the endogenous variable (performance) with the exogenous one (realized market volatility) and perform ordinary least square regressions, where the regression coefficients are both consistent and unbiased. The reduced form regressions show a strong negative and significant correlation between fund flows and market uncertainty, while I control for other market-wide and fund-specific variables. The estimates from 2SLS second stage can be understood as re-scaled coefficient from the reduced form. Thus, I expect a positive and significant coefficient of fund performance in the flow regression. ${ }^{27}$ As predicted, IV specification reports positive and statistically significant coefficients on $\operatorname{Perf}_{f, t}$ in table 3 columns 10 to 12 . It seems that OLS underestimates the size of the coefficient. In the IV specification, a one standard deviation

\footnotetext{
${ }^{27}$ The coefficient on performance in 2 SLS second stage is equal to the ratio of realized volatility coefficient in the first stage to realized volatility coefficient in the reduced form regression.
} 
decrease in performance reduces the percentage net flows by $0.2 \%$. This applies that fund's average flow falls by $\$ 2,259,180$ from $\$ 8,515,500$ to $\$ 6,256,320 .^{28}$

According to Vayanos (2004) when markets are uncertain, it is more likely that a fund performance falls below a benchmark. However OLS regressions show only the average effect of market volatility on fund performance. In order to investigate the impact of market uncertainty on the distribution of fund performance, I use a quantile regression approach, which estimate the effect of market uncertainty at different points of fund performance conditional distribution. Figure 3 shows quintile regression estimated coefficients of realized market volatility from the model in equation 9 for the 10th, 25th, 50th, 75th, and 90th percentile. The regression coefficient at a given quantile indicates the effect of a one standard deviation increase in market uncertainty on fund performance, assuming that the other variables are fixed, with $95 \%$ confidence interval bands. The figure shows that a fund's performance response to market uncertainty is heterogeneous. The dispersion of fund performance increases with market volatility. Specifically, the upper quartile performance remains unaffected by high market volatility, whereas bad performance deteriorates even further.

The estimates of the second step from equation 10 are reported in table 4 . The first three columns present OLS regression estimates of fund active liquidity management on its net flows. The Flow $_{f, t}$ coefficient is negative and insignificant in each specification, meaning that mutual fund liquidity preferences are unresponsive to redemption obligations. However, the $\gamma_{1}$ coefficient from equation 10 might be biased because of omitted variable problem (e.g. unobservable timevarying manager's skill) discussed in section 3.2. Thus, I use instrumental variable approach and instrument endogenous fund flows with market realized volatility. Columns 4 to 6 show the reduced form regressions. The coefficient on market uncertainty is negative and statistically significant. Therefore, I expect coefficient on instrumented flows in the active liquidity management regression to be positive and significant. ${ }^{29}$ When I isolate the part of the variation in fund flows that is induced by market uncertainty (by instrumenting fund's flows with market realized volatility), the Flow $f, t$ coefficient changes its sign to a positive one (compared with a negative sign in OLS regressions) and remains strongly significant - columns 7 to 9 . This implies, that market uncertainty induced outflows are associated with funds actively increasing liquidity of their portfolio. The effect is substantial: a one standard deviation decrease in fund flows is related to a 1.9 standard deviation increase in a fund's flight-to-liquidity.

To examine the impact of funds' active liquidity management on market liquidity premium, I re-estimate equations 8 to 10 in case of one large equity fund consisting of all the funds in my sample. I compute funds' aggregate performance, flows, and active liquidity management measure by calculating monthly averages weighted by market capitalization of funds' holdings. I expect

\footnotetext{
${ }^{28}$ The fund average TNA (unreported) is 1,050 millions. The average monthly flow is: $0.811 \% \cdot \$ 1,050 \mathrm{Mio} .=$ 8.5155 Mio. One standard deviation increase in realized volatility reduces the percentage net flows approximately by $0.2 \%=0.811 \%-0.22 \cdot 0.987 \%$. This means that the fund's average netflow is reduces by $\$ 2,259,180$ to $\$ 6,256,320$.

${ }^{29}$ The 2SLS first stage of fund behaviour regression is in table 3 in columns $7-9$.
} 
that in times of market uncertainty funds' aggregate liquidity preferences create a price pressure in the equity market. Specifically, while the redemption obligations increase with market uncertainty, mutual funds prepare themselves for possible withdrawals by increasing liquidity of their portfolio. They demand more liquid stocks pushing their prices up. On the other hand, illiquid stocks become less attractive because they entail high costs when they have to be liquidated (e.g. in order to meet redemptions). The prices of illiquid stocks are expected to decrease because mutual funds require higher return as a compensation for greater liquidation risk. Consequently, the realized return on a zero-cost portfolio (long in the quintile with the most illiquid stocks and short in the quintile with most liquid one) declines as well. Table 5 reports the aggregate time series regression estimates from equations $8-11$. Columns 1 and 2 show reduced form regressions of aggregate fund performance and flows on the realized market volatility. Similar to the estimates from panel regressions, the aggregate regressions report a negative impact of market uncertainty on fund performance and net flows. OLS regression estimates of equation 11 are reported in columns 6 through 9 in Table 5. The estimated OLS coefficients show a positive and statistically significant effect of funds' aggregate liquidity preferences on the measured return spread between illiquid and liquid portfolio. This means that an increase in mutual fund aggregate demand for liquid stocks create a downward price pressure on illiquid stocks, and thus the return spread decreases as well.

However, the $\delta_{1}$ from equation 11 might be biased because of the simultaneity problem rooted in the analysis of the prices on quantities that I described in subsection 3.2. Therefore, I use instrumental variable approach to mitigate the endogeneity issue. Columns 3 to 5 report coefficient estimates from the 2SLS first stage regression, where I regress the aggregate funds' active liquidity management measure (which increases with illiquidity) on the realized market volatility. Analogous to the panel regressions (in table 4), the aggregate time-series regressions show a negative relationship between market uncertainty and a measure of fund liquidity preferences. An increase in market volatility results in mutual funds tilting their portfolio towards more liquid assets. Columns 9 to 11 report the reduced form regressions, where I substitute the endogenous active liquidity management with exogenous realized market volatility. When the market volatility increases, the return spread between illiquid and liquid portfolios narrow. The market uncertainty coefficient from the reduced form regression is negative and highly significant, implying a positive and significant effect of fund behaviour on the return differential.

In the last three columns of table 5, I report the coefficient estimates from instrumental variable approach. I use the exogenous variation of realized market volatility as the instrument for funds' aggregate liquidity preferences and regress the return on a zero-cost portfolio on the instrumented liquidity management and other control variables that are supposed to capture the effect of liquidity supply (e.g. market-wide liquidity measure Noise $_{t}$ and funding liquidity measure TEDSpread ${ }_{t}$ ). In all specifications the $B_{t}$ coefficient is positive and significant, providing similar results to the OLS regressions. However, OLS seems to underestimate the impact of funds' active liquidity management. A one standard deviation increase in aggregate fund liquidity preferences (one standard deviation decrease in the measure), decreases the return spread by $2.13 \%$ from $0.012 \%$ to $-2.118 \%$ 
$(0.63 \cdot 3.381 \%) .30$

\subsection{Heterogeneity}

Up to this point I only use market volatility over-time variation that is common to all funds. However, a fund's exposure to market uncertainty depends on the exposure of its holdings. Because of differences across funds' holdings compositions, mutual funds' exposure to market uncertainty differ as well. In order to capture the diversity of funds' responses to market uncertainty arising from the exposure of the individual holdings, I construct a fund specific realized volatility measure. I use daily (high, low, open, close) prices for ten S\&P 500 Sector Indices that I obtained from Bloomberg, and compute the realized volatilities for each sector following Garman and Klass (1980). Then I match fund holdings to the ten GICS sectors. ${ }^{31}$ I calculate a fund specific realized volatility by taking a weighted average of sector realized volatilities with weights equal to the percentage of the portfolio invested in each of the sectors. I expect that mutual funds respond stronger to their fund specific realized volatilities, which reflect more precisely the exposure of the holdings to market uncertainty. I call my analysis of assessing the heterogeneity in a fund's active liquidity management to market uncertainty, measured with a fund specific realized volatility, a 'direct approach.'

Table 6 reports the results of the direct approach. In the first column I regress funds' liquidity preferences on overall market realized volatility (as in the previous analysis), thus it serves as a reference point. ${ }^{32}$ In the second column, I estimate the impact of a fund-specific realized volatility on the active liquidity management of a fund. The size of the coefficient on the fund-specific realized volatility is indeed larger (by around 16\%) than the coefficient on market-wide realized volatility. ${ }^{33}$ However, fund-specific realized volatility relies on fund-specific sector weights, that are simultaneously determined with the active liquidity management decision $B_{t, f}$. In order to mitigate the endogeneity problem, I construct an exogenous fund-specific realized volatility measure $R V_{o l}^{E X}$ that uses sector weights different from actual ones. In column 3, I use weights that correspond to the average of fund-specific sector weights over previous three months. In column 4, instead of value-weighting I use equal weights for sector realized volatilities. 2SLS second stage regressions are presented in columns 5 to 6 . The size of the instrumented coefficient on the fund-specific realized volatility (0.074) remains larger than overall market realized volatility coefficient (0.061) in column 1. This implies that market-wide realized volatility captures funds' exposure to uncertainty in a

\footnotetext{
${ }^{30} 0.011 \%, 3.381 \%$ are the unreported mean and standard deviation of value-weighted liquidity premium.

${ }^{31} \mathrm{~S} \& \mathrm{P} 500$ sector and industry indices use Global Industry Classification Standards (GICS) as well.

${ }^{32}$ The time period of the analysis is limited to 144 months from January 2002 to December 2013, because of the sector indices data availability.

${ }^{33}\left(\frac{0.071}{0.061}-1\right) \cdot 100 \%=16.4 \%$
} 
noisy manner and funds' responses depend on uncertainty that is embedded in their holdings. Once the exposure of the holdings to market uncertainty is more precisely identified, a fund's response becomes stronger.

Existing literature (e.g. Chordia (1996)) suggests that in equilibrium investors with high liquidation risk choose to invest in those mutual funds that charge lower load fees and hold more liquid assets. This implies that mutual funds differ from each other in terms of their initial liquidity positions. Redemptions are costly for a mutual fund for two reasons: unnecessary trading expenses, and cash holdings compromising fund performance. When market uncertainty increases, illiquid mutual funds face potentially higher costs of meeting withdrawals, and thus they are expected to respond stronger to the increases in market volatility. ${ }^{34}$ In order to examine the relationship between a fund's initial liquidity position and its response to market uncertainty, I develop a measure of an 'illiquidity shock' for each fund. This measure is supposed to capture shocks to a portfolio's liquidity that are independent of a manager's decision. More precisely, I use the component of the change in a portfolio's liquidity stemming from the shift due to a change in the market-wide liquidity of the holdings (their Amihud measure). A fund-specific liquidity shock is defined as a percentage change in the liquidity of a portfolio keeping a fund's investment decision constant: ${ }^{35}$

$$
\text { IlliqShock }_{f, t}=\frac{\sum_{s=1}^{S_{f, t-1}} \omega_{f, t-1}^{s}\left(\text { Illiq }_{s, t}-I_{l l i q_{s, t-1}}\right)}{\sum_{s=1}^{S_{f, t-1}} \omega_{f, t-1}^{s} \text { Illiq }_{s, t}},
$$

where $\omega_{f, t-1}^{s}$ and $I l l i q_{s, t}$ are defined in section 2.2.1. In my analysis, to which I refer as the 'indirect approach', the main variable of interest is the interaction term between a fund-specific illiquidity shock and market realized volatility. I expect funds experiencing an exogenous shock to the liquidity of their portfolio (they become more illiquid) respond stronger to uncertainty in the market, and thus tilt their portfolio towards liquid assets more aggressively.

Table 6 columns 7 and 8 show estimated coefficients from the regression of a mutual fund active liquidity management measure on market realized volatility, a fund-specific liquidity shock and other control variables. The IlliqShock $_{f, t}$ coefficient in column 7 is negative and statistically significant, as is the effect of market uncertainty. This may imply that mutual funds target the liquidity of their portfolios. When they experience exogenous illiquidity shock, they actively trade stocks in order to mitigate the effect of the shock. This result supports the theoretical model of Ang et al. (2014), who predict that investors have an optimal composition of liquid and illiquid assets, and whenever it is possible they rebalance their portfolios to the optimal ratio. Column 8 shows the interaction term between a fund-specific illiquidity shock and market realized volatility. The interaction coefficient is negative and significant, meaning that those mutual funds that are

\footnotetext{
${ }^{34}$ See also Manconi et al. (2012), who show that among funds holding 'toxic' securitized bonds, those with high turnover and high volatility of their flows react stronger to liquidity dry-ups by liquidating more of corporate bonds to meet redemptions.

${ }^{35}$ The illiquidity shock is obtained from the shift-share analysis of a change in a portfolio's liquidity in equation 4.
} 
subject to the illiquidity shock in times of high market uncertainty more aggressively change their portfolio towards more liquid stocks. The main effects of realized market volatility and illiquidity shock remain negative, yet insignificant.

\section{Robustness Test}

To check the robustness of my findings, I re-estimate equation 10, but use alternative measures of stock liquidity - the bid-ask spread and a log transformation of Amihud measure. I also incorporate the cash holdings, which constitute a considerable part (on average $3.2 \%$ ) of a portfolio, to the active liquidity manageent measure. Finally, I use only the non-forecastable component of market volatility and I re-estimate the set of equation $8-11$.

\subsection{Cash Holdings}

Stock holdings constitute only one part of mutual fund's portfolio. A skilful cash management can contribute to a fund's flexibility. Managers with available cash can react quickly to new information by purchasing an attractive stock or avoid costly fire sales by meeting redemptions with their cash buffer. ${ }^{36}$ Cash is infinitely liquid, therefore it is important to include it into my analysis. When a mutual fund faces a threat of withdrawal, it can enhance the liquidity of the portfolio either by increasing cash holdings or by increasing a fraction of liquid equities. Consequently, cash and equity decisions are interrelated and treating them separately can provide an erroneous result. In order to capture the interaction between cash and equity decisions, I include cash in my active liquidity management measure. The square-root transformation of Amihud measure allows me to incorporate cash holdings without any difficulties. Thus, I assign the lowest value (zero) of Amihud measure to cash. In columns 1 to 2,5 to 6 , and 9 to 10 in table 7, I use the active liquidity management measure computed with the square-root transformation of Amihud measure incorporating cash and repeat the same analysis from table 4 . The results are similar: volatility-induced outflows are strongly associated with managers increasing liquidity of their portfolio. Columns 1 and 2 report OLS regression estimates, and columns 9 and 10 show IV coefficients from the regressions of the active liquidity management with cash on fund's net flows. In case of OLS regression the coefficient on Flow $f, t$ is negative and significant. However, when I isolate the variation in fund flows that stems from market uncertainty, the fund flow coefficient changes its sign and remains highly significant. By incorporating cash into funds' liquidity preferences, the effect of volatility-induced net flows on the active liquidity management measure remain almost unaltered.

Some of the existing studies (Chordia (1996) and Huang (2015)) treat cash decision separately. Consequently, I replace the active liquidity management measure $B_{f, t}$ in equation 10 with the

\footnotetext{
${ }^{36}$ See e.g. Edelen (1999), Coval and Stafford (2007), Simutin (2013).
} 
percentage of holdings held in the form of cash and report the estimates in table $7 .{ }^{37}$ Flow $_{f, t}$ coefficient estimates from OLS cash holdings regressions in columns 3 and 4 is positive and significant. This suggests that cash holdings decrease with funds' outflows. The reduced form regressions in columns 7 to 8 report a positive and significant effect of realized market volatility on the level of cash holdings. Columns 11 and 12 show the IV results. The coefficient on Flow $w_{f, t}$ changes it sign to a negative one and remains significant (as it does in active liquidity management regression in table 4), when I only use the variation in funds' flows that is induced by market volatility. This means that fund managers increase the level of percentage cash holdings when they face uncertainty induced withdrawals. A one standard deviation decrease in fund flows increases on average cash holdings by $0.8 \%$ from $3.2 \%$ to $4.00 \%(0.92 \cdot 0.959 \%) .{ }^{38}$

\subsection{Alternative Liquidity Measures}

Throughout my analysis, I use the square-root transformation of Amihud measure because it enables me to incorporate cash holdings into a fund's active liquidity management measure. However, some of the existing studies on stock liquidity choose a log transformation of Amihud measure to reduce the influence of the extreme outliers. ${ }^{39}$ I also use the bid-ask spread as a measure of stock liquidity by averaging the daily proportional bid-ask spread over a month. ${ }^{40}$ The results with alternative liquidity measures are reported in table 8. Both the reduced form and 2SLS second stage regression estimates confirm the previous results. Volatility induced outflows are strongly associated with fund managers actively shifting their portfolio towards more liquid assets. This result is robust irrespective of the stock liquidity measure I use.

\subsection{Market Volatility Shock}

I re-estimate the set of equations 8 to 11 using an alternative measure of market uncertainty. I use the volatility shock, that is a non-forecastable component of realized market volatility. I regress current Garman and Klass (1980) realized market volatility on this month forecast VIX, and use the residual from this regression as the measure of the shock part of market volatility - Res $(\operatorname{Vol})_{t}$. I report the estimates from reduced form and second stage panel regressions of funds' performance,

\footnotetext{
${ }^{37}$ The first stage regressions have been already reported in table 3 columns 4 through 6 .

${ }^{38}$ My empirical results are supported by Chordia (1996), who shows that equity mutual funds increase their cash holdings when facing more redemption uncertainty.

${ }^{39}$ See e.g.: Brennan, Huh, and Subrahmanyam (2013), Hameed, Kang, and Viswanathan (2010), and Karolyi, Lee, and Van Dijk (2012)

${ }^{40} \mathrm{I}$ compute the weighted average for each portfolio as in equation 3 , and then decompose the change in the holdings - equation 4.
} 
flows, active liquidity management and time-series regressions of the measured return spread in table 9. Each row of the table reports the estimated coefficient and t-statistics for the variable of interest and other control variables. In each of the eight reduced form regressions, the estimated coefficient of volatility shock has the same sign, is similar in the size to the coefficient on realized volatility in tables 3 to 5 , and remains highly statistically significant. These results show that the previous results are not just an artefact of market volatility predictability, but rather that a fund's performance, flows and liquidity preferences respond to the non-forecastable component of market volatility, which results in the time-varying market price of liquidity.

By using the variation in funds' aggregate active liquidity management induced by market volatility shock, I show that mutual funds' liquidity preferences have a significant impact on the market liquidity premium. As a proxy for the market price of liquidity, I choose the return on the zero-cost portfolio that is long in the quintile of the most illiquid stocks and short in the quintile with the most liquid ones. The reduced form regressions in columns 11 and 12 report a negative relationship between unanticipated market volatility and the return spread. The coefficients on the instrumented funds' aggregate liquidity preferences in columns 13 and 14 are positive, significant and of the comparable size to the coefficient in table 5 column 14. A one standard deviation decrease in the behaviour measure (increase in the liquidity of the aggregate portfolio) decreases the return spread by $2.06 \%$ from $0.012 \%$ to $-2.048 \%$.

\section{Conclusion}

I contribute to the empirical asset pricing literature by providing a potential explanation for the relationship between the market price of liquidity and the uncertainty. While existing research investigates the impact of market uncertainty on mutual fund capital flows, a direct link between uncertainty-induced fund behaviour and the market price of liquidity have not been examined. This paper bridges this gap by showing one channel through which market uncertainty impacts the liquidity premium.

This empirical study builds on Vayanos (2004)'s theoretical framework, where investors withdraw their money when a fund's performance falls below a given threshold, which is more likely during times of high market uncertainty. Consequently, managers facing a threat of increasing redemption obligations tilt their portfolio toward more liquid stocks to minimize future transaction costs. This aggregate shift in a fund's liquidity preference translates into a market level increase in the price of liquidity. To examine the described mechanism, I measure a fund's active liquidity management using data from Morningstar on monthly holdings of US active mutual funds investing in US equity between January 1998 and December 2013. I obtain the measure by isolating the change in a portfolio's liquidity that is due to a manager's decision over a holding's composition.

Using this measure of active liquidity management, I study the response of a fund to uncertaintyinduced net flows. OLS estimates suggests that funds do not respond to their flows. However, OLS 
estimates are potentially biased by unobservable time-variation in the data that is correlated with fund flows. To address this endogeneity concern I use market volatility as an instrument to identify the causal effect of uncertainty on the liquidity of a mutual fund - a procedure that arises naturally from the structure of Vayanos's (2004) model.

I provide empirical evidence of a negative relationship between fund net flows and market uncertainty, which is consistend with existing research (Ederington and Golubeva (2011) and Ferson and Kim (2012)). By isolating the variation in fund flows induced by market volatility, I show that mutual funds actively manage the liquidity of their portfolios in response to their redemption obligations. A one standard deviation decrease in fund's net flows causes a 1.9 standard deviation increase in an actively managed portfolio's liquidity. I also find consistent results when I include cash holdings into the active liquidity management measure or examine fund cash management separately. Mutual fund managers increase the liquidity of their portfolio by tilting their positions towards more liquid stocks and expanding their cash holdings. However, these results do not provide any insight on the heterogeneity of a fund's response to the redemption obligation, because I use over-time variation that is common to all funds. I address this issue by constructing a fund-level uncertainty measure, and I show that a fund's exposure to the volatility depends on the exposure of their holdings. I also find that mutual funds experiencing an adverse shock to the liquidity of their holdings tilt their portfolio towards more liquid stocks and rebalance their positions even more aggressively when market volatility is high.

These results indicate that mutual funds have time-varying liquidity preferences. Applying Vayanos's theoretical framework to my empirical analysis, I show that a volatility-induced aggregate increase in a fund's actively managed portfolio's liquidity will exert a downward price pressure on illiquid stocks. A return on a zero-cost portfolio, which is long in illiquid and short in liquid stocks, decreases in response to mutual funds' aggregate shift towards liquid assets. The effect is substantial: a one standard deviation increase in a fund's liquidity preference, decreases the measured return spread by 2.13 percent.

This paper provides a rational explanation of asset mispricing. Based on my analysis, I show that many mutual funds follow the same strategy by actively increasing liquidity of their portfolios when they expect their redemption obligations to increase. Whereas transactions of a single fund have no significant market impact, an aggregate shift in funds' liquidity preferences could potentially deviate prices from their fundamental values. I show that when market uncertainty increases, many mutual funds contemporaneously face possible withdrawals and thus tilt their portfolio towards more liquid assets at the same time. Consequently, the market-wide price of liquidity increases and illiquid stocks are adversely affected by this non-fundamental shift in funds' demand. 


\section{REFERENCES}

Acharya, V. and L. H. Pedersen (2005). Asset pricing with liquidity risk. Journal of Financial Economics 77, 375-410.

Amihud, Y. (2002). Illiquidity and stock returns: cross-section and time-series effects. Journal of Financial Markets 5, 31-56.

Amihud, Y. and H. Mendelson (1986). Asset pricing and the bid-ask spread. Journal of Financial Economics 17, 223-249.

Ang, A., D. Papanikolaou, and M. M. Westerfield (2014). Portfolio Choice with Illiquid Assets. Management Science 60(11), 2737-2761.

Anton, M. and C. Polk (2014). Connected stocks. The Journal of Finance 69(3), 1099-1127.

Asness, C. S., A. Frazzini, and L. H. Pedersen (2013). Quality Minus Junk. AQR Capital Management Working Paper, 1-60.

Beber, A., M. W. Brandt, and K. A. Kavajecz (2009). Flight-to-quality or flight-to-liquidity? Evidence from the euro-area bond market. Review of Financial Studies 22(3), 925-957.

Ben-Rephael, A. (2014). Flight-to-Liquidity, Market Uncertainty, and the Actions of Mutual Fund Investors. Indiana University Working Paper, 1-74.

Bernardo, E. and I. Welch (2004). Liquidity and Financial Market Runs. The Quarterly Journal of Economics 119(1), 135-158.

Brennan, M., S.-W. Huh, and A. Subrahmanyam (2013). An Analysis of the Amihud Illiquidity Premium. Review of Asset Pricing Studies 3, 133-176.

Brennan, M. J. and A. Subrahmanyam (1996). Market microstructure and asset pricing: On the compensation for illiquidity in stock returns. Journal of Financial Economics 41(3), 441464 .

Brunnermeier, M. K. and L. H. Pedersen (2009). Market liquidity and funding liquidity. Review of Financial Studies 22, 2201-2238.

Campbell, J. Y. and L. Hentschel (1992). No news is good news : An asymmetric model of changing volatility in stock returns. Journal of Financial Economics 31, 281-318.

Chen, Q., I. Goldstein, and W. Jiang (2010). Payoff complementarities and financial fragility: Evidence from mutual fund outflows. Journal of Financial Economics 97(2), 239-262.

Chernenko, S. and A. Sunderam (2015). Liquidity Transformation in Asset Management: Evidence from the Cash Holdings of Mutual Funds. Ohio State University Working Paper, 1-42. 
Chordia, T. (1996). The structure of mutual fund charges. Journal of Financial Economics 41(1), $3-39$.

Chordia, T., S.-W. Huh, and A. Subrahmanyam (2009). Theory-Based Iliquidity and Asset Pricing. Review of Financial Studies 22(9), 3629-3668.

Christoffersen, S. E., D. K. Musto, and R. Wermers (2014). Investor Flows to Asset Managers: Causes and Consequences. Annual Review of Financial Economics 6(1), 289-310.

Chung, K. H. and C. Chuwonganant (2014). Uncertainty, market structure, and liquidity. Journal of Financial Economics 113(3), 476-499.

Constantinides, G. M. (1986). Capital Market Equilibrium with Transaction Costs. The Journal of Political Economy 94(4), 842-962.

Coval, J. and E. Stafford (2007). Asset fire sales (and purchases) in equity markets. Journal of Financial Economics 86, 479-512.

Dunn, E. S. (1960). A Statistical and Analytical Technique for Regional Analysis. The Regional Science Association 6, 97-112.

Edelen, R. M. (1999). Investor flows and the assessed performance of open-end mutual funds. Journal of Financial Economics 53, 439-466.

Ederington, L. and E. Golubeva (2011). The Impact of Stock Market Volatility Expectations on Investor Behavior : Evidence From Aggregate Mutual Fund Flows. Universtiy of Oklahoma Working Paper, 1-39.

Elton, E. J., M. J. Gruber, C. R. Blake, Y. Krasny, and S. O. Ozelge (2010). The effect of holdings data frequency on conclusions about mutual fund behavior. Journal of Banking and Finance 34(5), 912-922.

Ferson, W. E. and M. S. Kim (2012). The factor structure of mutual fund flows. International Journal of Portfolio Analysis and Management 1(2), 112-143.

French, K. R., G. W. Schwert, and R. F. Stambaugh (1987). Expected Stock Returns and Volatility. Journal of Financial Economics 19(1), 3-29.

Gârleanu, N. and L. H. Pedersen (2007). Liquidity and Risk Management. The American Economic Review (97), 193-197.

Garman, M. B. and M. J. Klass (1980). On the Estimation of Security Price Volatilities from Historical Data. The Journal of Business 53(1), 67-78.

Gennotte, G. and H. Leland (1990). Market Liquidity, Hedging, and Crashes. The American Economic Review 80(5), 999-1021. 
Greenwood, R. and D. Thesmar (2011). Stock price fragility. Journal of Financial Economics 102(3), 471-490.

Gruber, M. J. (1996). Another Puzzle : The Growth in Actively Managed Mutual Funds. The Journal of Finance 51(3), 783-810.

Hagströmer, B., B. Hansson, and B. Nilsson (2013). The components of the illiquidity premium: An empirical analysis of US stocks 1927-2010. Journal of Banking E Finance 37(11), 44764487.

Hameed, A., W. Kang, and S. Viswanathan (2010). Stock market declines and liquidity. Journal of Finance 65(1), 257-293.

Hasbrouck, J. (2009). Trading Costs and Returns for U.S. Equities: Estimating Effective Costs from Daily Data. Journal of Finance 64(3), 1445-1477.

Hu, G. X., J. Pan, and J. Wang (2013). Noise as Information for Illiquidity. Journal of Finance 68(6), 2341-2382.

Huang, J. (2015). Dynamic Liquidity Preferences of Mutual Funds. University of Illinoise Working Paper, 1-47.

Huang, J. and J. Wang (2009). Liquidity and Market Crashes. Review of Financial Studies 22(7), $2607-2643$.

Ippolito, R. A. (1992). Consumer Reaction to Measures of Poor Quality: Evidence from the Mutual Fund Industry. The Journal of Law and Economics 35(1), 45-70.

Jensen, G. R. and T. Moorman (2010). Inter-temporal variation in the illiquidity premium. Journal of Financial Economics 98(2), 338-358.

Kacperczyk, M., S. van Nieuwerburgh, and L. Veldkamp (2014). Time-Varying Fund Manager Skill. The Journal of Finance 69(4), 1455-1484.

Kamstra, M. J., L. A. Kramer, M. D. Levi, and R. Wermers (2012). Seasonal Asset Allocation : Evidence from Mutual Fund Flows Seasonal Asset Allocation: Evidence from Mutual Fund Flows Abstract. Number December.

Karolyi, G. A., K.-H. Lee, and M. A. Van Dijk (2012). Understanding commonality in liquidity around the world. Journal of Financial Economics 105(1), 82-112.

Koch, A., S. Ruenzi, and L. T. Starks (2012). Commonality in Liquidity: A Demand-Side Explanation. University of Texas Working Paper.

Krishnamurthy, A. (2010). Amplification Mechanisms in Liquidity Crises. American Economic Journal: Macroeconomics 2(3), 1-30. 
Liu, X. and A. S. Mello (2011). The fragile capital structure of hedge funds and the limits to arbitrage. Journal of Financial Economics 102(3), 491-506.

Longstaff, F. A. (2004). The Flight-to-Liquidity Premium in U.S. Treasury Bond Prices. Journal of Business 77(3), 511-526.

Longstaff, F. A., J. Pan, L. H. Pedersen, and K. J. Singleton (2011). How sovereign is sovereign credit risk? American Economic Journal: Macroeconomics 3(2), 75-103.

Lou, D. (2012). A flow-based explanation for return predictability. Review of Financial Studies 25(12), 3457-3489.

Lynch, A. W. and D. K. Musto (2003). How investors interpret past fund returns. The Journal of Finance 58(5), 2033-2058.

Malherbe, F. (2014). Self-fulfilling liquidity dry-ups. Journal of Finance 69(2), 947-970.

Manconi, A., M. Massa, and A. Yasuda (2012). The role of institutional investors in propagating the crisis of 2007-2008. Journal of Financial Economics 104(3), 491-518.

Morris, S. and H. S. Shin (2004). Liquidity black holes. Review of Finance 8(1), 1-18.

Nagel, S. (2012). Evaporating liquidity. Review of Financial Studies 25(2009), 2005-2039.

Pástor, L. and R. F. Stambaugh (2003). Liquidity Risk and Expected Stock Returns. The Journal of Political Economy 111(3), 642-685.

Petersen, M. A. (2009). Estimating standard errors in finance panel data sets: Comparing approaches. Review of Financial Studies 22(1), 435-480.

Phillips, B., K. Pukthuanthong, and P. R. Rau (2013). Limited Attention , Horizon Effects, and the Uninformative Persuasion of Mutual Fund Investors. University of Waterloo Working Paper, 1-67.

Reuter, J. and E. Zitzewitz (2015). How Much Does Size Erode Mutual Fund Performance? A Regression Discontinuity Approach. Boston College Working Paper, 1-65.

Simutin, M. (2013). Cash Holdings and Mutual Fund Performance. Review of Finance 18(4), $1425-1464$.

Sirri, E. R. and P. Tufano (1998). Costly Search and Mutual Fund Flows. The Journal of Finance 53(5), 1589-1622.

Vayanos, D. (2004). Flight To Quality, Flight To Liquidity, and the Pricing of Risk. NBER Working Paper, 1-53.

Zheng, L. (1999). Is Money Smart? A Study of Mutual Fund Investors' Fund Selection Ability. The Journal of Finance 54(3), 901-933. 
Figure 1: Fund Aggregate Performance and Realized Market Volatility.

This figure shows time series of Garman and Klass (1980) monthly realized market volatility (black) and aggregate performance of US active equity mutual funds investing in US equity (grey) from January 1998 to December 2013. Both fund performance and market volatility are z-scored. The shaded gray areas depict periods of the highest market volatility.

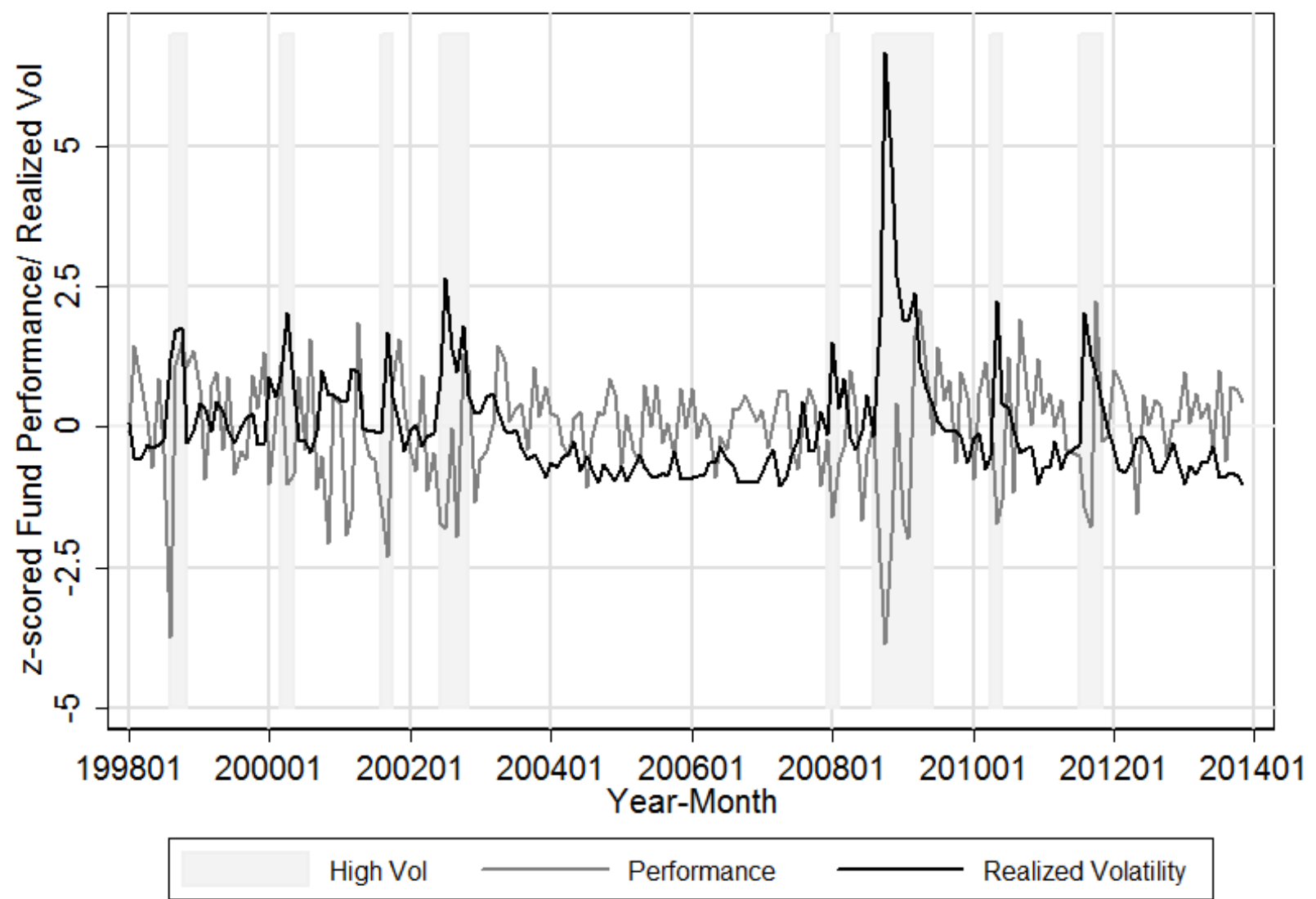

This preprint was prepared with the AAS LATEX macros v5.2. 
Figure 2: Fund Aggregate Flows and Realized Market Volatility.

This figure shows time series of Garman and Klass (1980) monthly realized market volatility (black) and aggregate net flows of US active equity mutual funds investing in US equity (grey) from January 1998 to December 2013. Both fund net flows and market volatility are z-scored. The shaded gray areas depict periods of the highest market volatility.

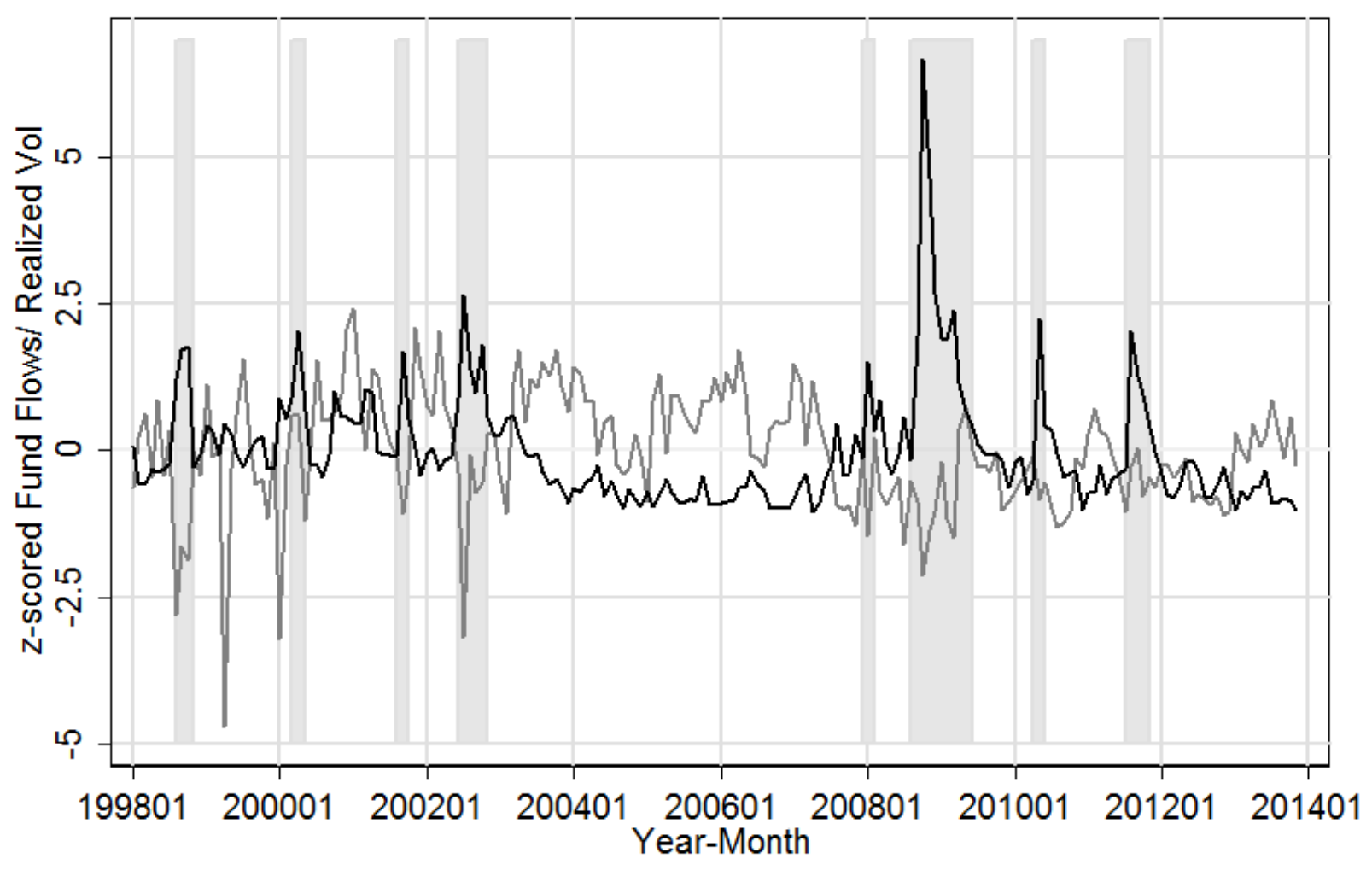

$$
\text { High Vol Flows } \longrightarrow \text { Realized Volatility }
$$


Figure 3: Quintile Regression of Fund Performance on Market Realized Volatility.

This figure graphically depicts realized volatility estimated coefficients from quintile regressions (for 10th, 25th, 50th, 75th, and 90th percentiles) of fund performance on market volatility, fixed effects and other control variables. The respective values are connected by the maroon solid line with accompanying estimated $95 \%$ confidence intervals shaded in grey.

\section{Quantile Estimates}

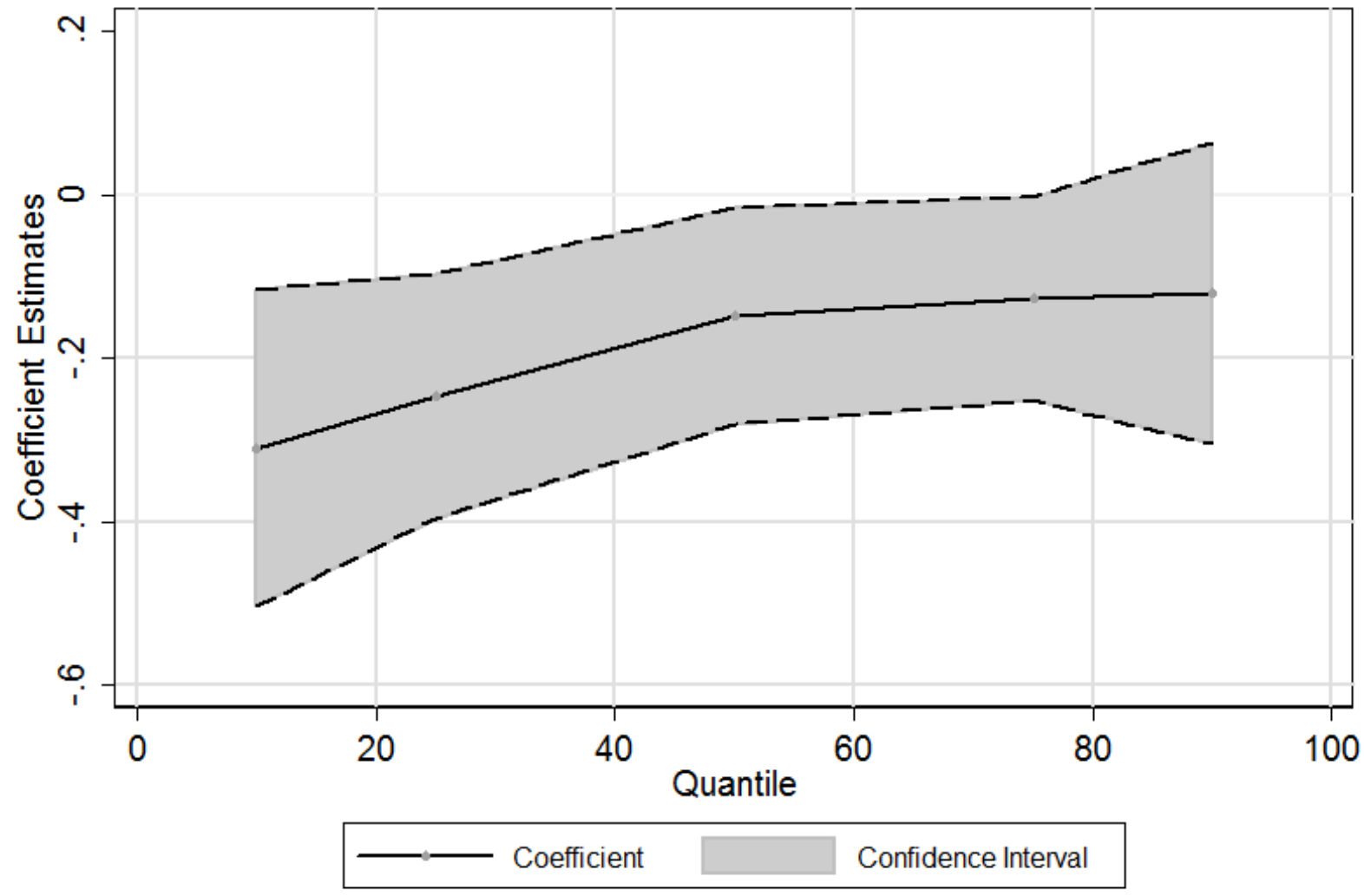


Table 1: Mutual Fund Summary Statistics.

This table shows summary statistics on the mutual fund sample obtained from the Morningstar database. The sample includes US active equity mutual funds investing in US equity that existed at any time during January 1998 through December 2013 for which monthly holdings information is available, overall 85,560 fund-month observations. No. Funds is the number of distinct funds each year in my sample. TNA is a total net assets. No. Stocks per Fund is a number of stocks held by a fund on average; No. Stocks is an average number of distinct stocks held by all mutual funds in the sample; Matching Rate is the percentage of the holdings value that has been successfully merged with CRSP stock data (mutual funds with matching rate lower than $70 \%$ are discarded from the sample).

\begin{tabular}{cccccccc}
\hline Year & $\begin{array}{c}\text { No. } \\
\text { Funds }\end{array}$ & TNA (\$ Million) & \multicolumn{2}{c}{$\begin{array}{c}\text { No. Stocks } \\
\text { per Fund }\end{array}$} & $\begin{array}{c}\text { No. } \\
\text { Stocks }\end{array}$ & $\begin{array}{c}\text { Matching } \\
\text { Rate }\end{array}$ \\
& & Mean & Median & Mean & Median & & \\
\hline 1998 & 169 & 1881.32 & 765.16 & 103 & 64 & 2285 & 0.81 \\
1999 & 234 & 1203.71 & 551.64 & 96 & 62 & 2365 & 0.82 \\
2000 & 296 & 1217.10 & 658.12 & 121 & 71 & 3193 & 0.83 \\
2001 & 374 & 1053.51 & 364.40 & 101 & 68 & 2469 & 0.86 \\
2002 & 525 & 1016.71 & 375.54 & 121 & 76 & 3053 & 0.89 \\
2003 & 689 & 878.33 & 252.05 & 121 & 77 & 3162 & 0.89 \\
2004 & 685 & 883.19 & 274.16 & 123 & 82 & 3203 & 0.87 \\
2005 & 584 & 1080.80 & 380.15 & 131 & 82 & 3252 & 0.88 \\
2006 & 535 & 961.79 & 316.34 & 124 & 82 & 3534 & 0.90 \\
2007 & 636 & 1430.40 & 665.75 & 162 & 85 & 3908 & 0.91 \\
2008 & 677 & 1406.80 & 541.72 & 184 & 89 & 3816 & 0.90 \\
2009 & 787 & 1191.11 & 457.29 & 195 & 95 & 3620 & 0.90 \\
2010 & 868 & 1475.04 & 560.56 & 201 & 93 & 3652 & 0.90 \\
2011 & 995 & 1743.75 & 579.85 & 189 & 90 & 3509 & 0.89 \\
2012 & 1004 & 1962.01 & 616.62 & 186 & 85 & 3417 & 0.89 \\
\hline & 1006 & 3468.98 & 743.83 & 191 & 88 & 3391 & 0.89 \\
\hline
\end{tabular}


Table 2: Summary Statistics: Funds' Performance, Flows, Behaviour Measures, and Other Control Variables.

Panel A shows summary statistics on the main variables used in this paper. Perf $f_{f, t}$ is fund's relative performance in percentage and it is calculated as fund's monthly net return minus the return on S\&P500. Flow $w_{f, t}$ is fund net flow relative to its lagged TNA. $\sqrt{I l l i q_{f, t}}$ is a value-weighted sqaure-root of Amihud measure for a mutual fund estimated from its holdings. $B_{f, t}$ is a measure of fund's active liquidity management. Cash $f, t$ is the

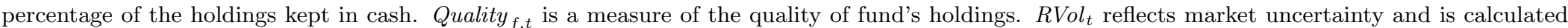
by Garman and Klass (1980) measure of realized volatility. $R_{M, t}$ is the return on S\&P500. $\Delta$ Noise $_{t}$ is a market-wide liquidity measure constructed by Hu et al. (2013). PSLiq $q_{t}$ is Pástor and Stambaugh (2003) equity market liquidity measure. TEDSpread reflects funding liquidity and is defined as the difference between 3-Month LIBOR based on US dollars and 3-Month Treasury Bill. For each item, I compute the cross-sectional averages in each month from January 1998 to December 2013 (I only have the data for fund's quality until December 2012). The reported statistics are computed from the time-series of the 192 monthly cross-sectional averages for each item. Panel B shows correlation computed from the time-series of the 192 monthly cross-sectional averages for each item.

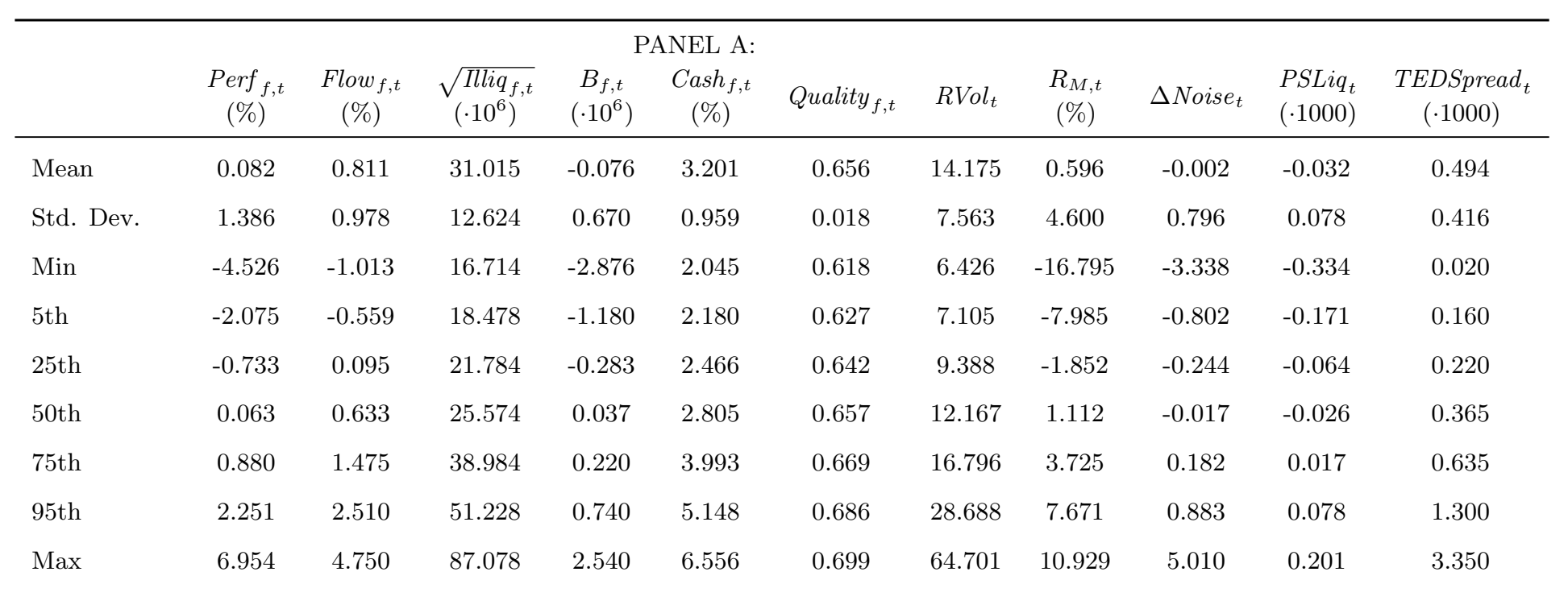




\begin{tabular}{|c|c|c|c|c|c|c|c|c|c|c|c|}
\hline \multicolumn{12}{|c|}{ PANEL B: } \\
\hline & $\begin{array}{l}\operatorname{Perf}_{f, t} \\
(\%)\end{array}$ & $\begin{array}{c}\text { Flow }_{f, t} \\
(\%)\end{array}$ & $\begin{array}{c}\sqrt{\operatorname{Illiq}_{f, t}} \\
\left(\cdot 10^{6}\right)\end{array}$ & $\begin{array}{c}B_{f, t} \\
\left(\cdot 10^{6}\right)\end{array}$ & $\begin{array}{c}\operatorname{Cash}_{f, t} \\
(\%)\end{array}$ & Quality $_{f, t}$ & $R V l_{t}$ & $\begin{array}{c}R_{M, t} \\
(\%)\end{array}$ & $\Delta$ Noise $_{t}$ & $\begin{array}{l}\text { PSLiq }_{t} \\
(\cdot 1000)\end{array}$ & $\begin{array}{c}\text { TEDSpread }_{t} \\
(\cdot 1000)\end{array}$ \\
\hline $\operatorname{Perf}_{t}$ & 1 & & & & & & & & & & \\
\hline Flow $_{f, t}$ & 0.12 & 1 & & & & & & & & & \\
\hline$\sqrt{\operatorname{Illiq}_{f, t}}$ & -0.12 & 0.0078 & 1 & & & & & & & & \\
\hline$B_{f, t}$ & 0.18 & 0.28 & -0.41 & 1 & & & & & & & \\
\hline $\operatorname{Cash}_{f, t}$ & -0.12 & 0.21 & 0.85 & -0.27 & 1 & & & & & & \\
\hline Quality $_{t}$ & -0.034 & -0.40 & -0.44 & 0.014 & -0.44 & 1 & & & & & \\
\hline$R \operatorname{Vol}_{t}$ & -0.22 & -0.32 & 0.48 & -0.42 & 0.27 & 0.024 & 1 & & & & \\
\hline$R_{M, t}$ & 0.11 & 0.14 & -0.067 & 0.073 & -0.038 & -0.067 & -0.40 & 1 & & & \\
\hline$\Delta$ Noise $_{t}$ & -0.16 & -0.014 & -0.0031 & -0.18 & 0.036 & 0.029 & 0.17 & -0.29 & 1 & & \\
\hline$P S \operatorname{Liq}_{t}$ & 0.069 & 0.12 & -0.26 & 0.20 & -0.16 & 0.065 & -0.40 & 0.18 & -0.095 & 1 & \\
\hline TEDSpread $_{t}$ & -0.12 & -0.12 & 0.25 & -0.28 & 0.22 & 0.19 & 0.48 & -0.24 & 0.39 & -0.26 & 1 \\
\hline
\end{tabular}


Table 3: First Stage, OLS and Instrumental Variable Panel Regressions of Fund's Flows on Fund's Performance and Other Control Variables.

This table uses monthly data from Morningstar from January 1998 through December 2013 (85,560 fund-month observations) to examine the relationship between fund's flows and its relative performance. All the variables (excluding Recession) are z-scored. Columns 1-3 show the coefficients from the 2SLS first stage regression of fund performance $\operatorname{Perf}_{f, t}$ on realized market volatility. Columns $4-6$ show the coefficients from OLS regression of flows Flow $f, t$ on funds' performance Perf $f, t$. Columns 7-9 report the reduced for regressions, where fund flows are regressed on realized market volatility. Columns 10-12 show instrumental variable regression coefficients. I use Garman and Klass (1980) realized market volatility $R V l_{t}$ as the instrument for the performance in the columns 10-12. I include control variables as: return on S\&P500 index $R_{M, t}$, Hu et al. (2013) measure of the market-wide liquidity $\Delta$ Noise $_{t}$, Pástor and Stambaugh (2003) measure of equity market liquidity PSLiq $t_{t}$, a measure of funding liquidity TEDSpread ${ }_{t}$, fund's value-weighted quality measure of its holdings Quality $_{f, t}$, and a dummy variable Recession is a dummy variable equal one if there was a NBER recession in a given month, otherwise zero. I control for fund, year and quarter fixed effects. The t-statistics reported in the tables reflect robust standard errors that are clustered both at year-month and a fund level.

\begin{tabular}{|c|c|c|c|c|c|c|c|c|c|c|c|c|}
\hline & \multicolumn{3}{|c|}{ First Stage } & \multicolumn{3}{|c|}{ OLS } & \multicolumn{3}{|c|}{ Reduced Form } & \multicolumn{3}{|c|}{ IV } \\
\hline & (1) & $(2)$ & (3) & (4) & (5) & (6) & (7) & (8) & (9) & (10) & (11) & (12) \\
\hline $\operatorname{Per} f_{f, t}$ & & & & $\begin{array}{l}0.021 \\
(3.10)\end{array}$ & $\begin{array}{l}0.018 \\
(2.66)\end{array}$ & $\begin{array}{l}0.018 \\
(2.55)\end{array}$ & & & & $\begin{array}{c}0.21 \\
(3.53)\end{array}$ & $\begin{array}{c}0.17 \\
(2.25)\end{array}$ & $\begin{array}{c}0.14 \\
(2.24)\end{array}$ \\
\hline$R V o l_{t}$ & $\begin{array}{c}-0.21 \\
(-4.74)\end{array}$ & $\begin{array}{c}-0.17 \\
(-2.72)\end{array}$ & $\begin{array}{c}-0.19 \\
(-2.92)\end{array}$ & & & & $\begin{array}{l}-0.043 \\
(-5.28)\end{array}$ & $\begin{array}{l}-0.029 \\
(-3.32)\end{array}$ & $\begin{array}{l}-0.027 \\
(-2.88)\end{array}$ & & & \\
\hline$R_{M, t}$ & & $\begin{array}{l}0.054 \\
(0.80)\end{array}$ & $\begin{array}{l}0.057 \\
(0.84)\end{array}$ & & $\begin{array}{l}0.027 \\
(3.89)\end{array}$ & $\begin{array}{l}0.026 \\
(3.70)\end{array}$ & & $\begin{array}{l}0.020 \\
(2.79)\end{array}$ & $\begin{array}{l}0.021 \\
(2.92)\end{array}$ & & $\begin{array}{l}0.011 \\
(0.63)\end{array}$ & $\begin{array}{l}0.013 \\
(0.81)\end{array}$ \\
\hline$\Delta$ Noise $_{t}$ & & $\begin{array}{l}-0.058 \\
(-1.21)\end{array}$ & $\begin{array}{l}-0.055 \\
(-0.96)\end{array}$ & & $\begin{array}{l}0.0066 \\
(1.04)\end{array}$ & $\begin{array}{l}0.0093 \\
(1.24)\end{array}$ & & $\begin{array}{l}0.0068 \\
(0.92)\end{array}$ & $\begin{array}{l}0.0083 \\
(0.94)\end{array}$ & & $\begin{array}{l}0.017 \\
(1.97)\end{array}$ & $\begin{array}{l}0.016 \\
(1.95)\end{array}$ \\
\hline PSLiq & & $\begin{array}{c}-0.0078 \\
(-0.15)\end{array}$ & $\begin{array}{l}0.0085 \\
(0.16)\end{array}$ & & $\begin{array}{l}0.019 \\
(2.89)\end{array}$ & $\begin{array}{l}0.018 \\
(2.72)\end{array}$ & & $\begin{array}{l}0.013 \\
(2.02)\end{array}$ & $\begin{array}{l}0.014 \\
(2.12)\end{array}$ & & $\begin{array}{l}0.014 \\
(1.42)\end{array}$ & $\begin{array}{l}0.013 \\
(1.37)\end{array}$ \\
\hline TEDSpread $_{t}$ & & & $\begin{array}{l}0.037 \\
(0.83)\end{array}$ & & & $\begin{array}{c}-0.0091 \\
(-1.05)\end{array}$ & & & $\begin{array}{c}0.00026 \\
(0.03)\end{array}$ & & & $\begin{array}{r}-0.0050 \\
(-0.58)\end{array}$ \\
\hline Quality $_{f, t}$ & & & $\begin{array}{l}0.055 \\
(1.78)\end{array}$ & & & $\begin{array}{l}-0.014 \\
(-0.84)\end{array}$ & & & $\begin{array}{l}-0.013 \\
(-0.80)\end{array}$ & & & $\begin{array}{l}-0.021 \\
(-1.22)\end{array}$ \\
\hline Recession & & & $\begin{array}{l}198.2 \\
(0.79)\end{array}$ & & & $\begin{array}{l}-8.25 \\
(-0.28)\end{array}$ & & & $\begin{array}{c}9.54 \\
(0.30)\end{array}$ & & & $\begin{array}{l}-18.8 \\
(-0.43)\end{array}$ \\
\hline
\end{tabular}




\begin{tabular}{lcccccccccccccc} 
Qtr FE & Yes & Yes & Yes & Yes & Yes & Yes & Yes & Yes & Yes & Yes & Yes & Yes \\
Year FE & Yes & Yes & Yes & Yes & Yes & Yes & Yes & Yes & Yes & Yes & Yes & Yes \\
Fund FE & Yes & Yes & Yes & Yes & Yes & Yes & Yes & Yes & Yes & Yes & Yes & Yes \\
YM Cluster & Yes & Yes & Yes & Yes & Yes & Yes & Yes & Yes & Yes & Yes & Yes & Yes \\
Fund Cluster & Yes & Yes & Yes & Yes & Yes & Yes & Yes & Yes & Yes & Yes & Yes & Yes \\
\hline Observations & 85560 & 85560 & 74609 & 85560 & 85560 & 74609 & 85560 & 85560 & 74609 & 85560 & 85560 & 74609 \\
$R^{2}$ & 0.066 & 0.072 & 0.081 & 0.16 & 0.16 & 0.17 & 0.16 & 0.16 & 0.17 & & \\
\hline
\end{tabular}


Table 4: First Stage, OLS and Instrumental Variable Panel Regressions of Fund's Behaviour on Fund's Flows and Other Control Variables.

This table uses monthly data from Morningstar from January 1998 through December 2013 (85,560 fundmonth observations) to examine the relationship between fund's behaviour and its net flows. All the variables (excluding Recession) are z-scored. Columns 1-3 show the coefficients from the first stage regression of fund flows Flow $_{f, t}$ on realized market volatility. Columns 4-6 show the coefficients from OLS regression of fund active liquidity management $B_{f, t}$ on fund's net flows $F_{l o w}, t$. Columns $7-9$ show instrumental variable regression coefficients. I use Garman and Klass (1980) realized market volatility $R V_{0} l_{t}$ as the instrument for the fund net flows in the columns 7-9. I include control variables as: return on S\&P500 index $R_{M, t}$, Hu et al. (2013) measure of the market-wide liquidity $\Delta$ Noise $_{t}$, Pástor and Stambaugh (2003) measure of equity market liquidity $P S L i q_{t}$, a measure of funding

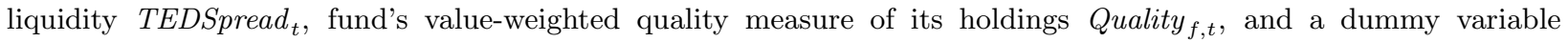
Recession is a dummy variable equal one if there was a NBER recession in a given month, otherwise zero. I control for fund, year and quarter fixed effects. The t-statistics reported in the tables reflect robust standard errors that are clustered both at year-month and a fund level.

\begin{tabular}{|c|c|c|c|c|c|c|c|c|c|}
\hline & \multicolumn{3}{|c|}{ OLS } & \multicolumn{3}{|c|}{ Reduced Form } & \multicolumn{3}{|c|}{ IV } \\
\hline & (1) & (2) & (3) & (4) & (5) & (6) & (7) & (8) & (9) \\
\hline Flow $_{f, t}$ & $\begin{array}{l}-0.0031 \\
(-1.18)\end{array}$ & $\begin{array}{l}-0.0037 \\
(-1.41)\end{array}$ & $\begin{array}{l}-0.0036 \\
(-1.31)\end{array}$ & & & & $\begin{array}{c}1.30 \\
(3.73)\end{array}$ & $\begin{array}{c}1.92 \\
(3.00)\end{array}$ & $\begin{array}{c}2.24 \\
(2.94)\end{array}$ \\
\hline$R V o l_{t}$ & & & & $\begin{array}{l}-0.057 \\
(-4.60)\end{array}$ & $\begin{array}{l}-0.058 \\
(-3.66)\end{array}$ & $\begin{array}{l}-0.062 \\
(-3.70)\end{array}$ & & & \\
\hline$R_{M, t}$ & & $\begin{array}{l}0.019 \\
(1.73)\end{array}$ & $\begin{array}{l}0.017 \\
(1.68)\end{array}$ & & $\begin{array}{c}-0.00027 \\
(-0.03)\end{array}$ & $\begin{array}{c}0.000098 \\
(0.01)\end{array}$ & & $\begin{array}{l}-0.039 \\
(-1.56)\end{array}$ & $\begin{array}{l}-0.049 \\
(-1.64)\end{array}$ \\
\hline$\Delta$ Noise $_{t}$ & & $\begin{array}{l}-0.014 \\
(-1.15)\end{array}$ & $\begin{array}{l}-0.011 \\
(-0.75)\end{array}$ & & $\begin{array}{l}-0.011 \\
(-0.92)\end{array}$ & $\begin{array}{l}-0.011 \\
(-0.79)\end{array}$ & & $\begin{array}{l}-0.026 \\
(-2.06)\end{array}$ & $\begin{array}{l}-0.034 \\
(-2.05)\end{array}$ \\
\hline$P S \operatorname{Piq}_{t}$ & & $\begin{array}{c}0.0040 \\
(0.31)\end{array}$ & $\begin{array}{c}0.0014 \\
(0.10)\end{array}$ & & $\begin{array}{c}-0.0095 \\
(-0.81)\end{array}$ & $\begin{array}{c}-0.0098 \\
(-0.79)\end{array}$ & & $\begin{array}{l}-0.031 \\
(-1.71)\end{array}$ & $\begin{array}{l}-0.038 \\
(-1.81)\end{array}$ \\
\hline TEDSpread $_{t}$ & & & $\begin{array}{l}-0.016 \\
(-0.87)\end{array}$ & & & $\begin{array}{l}0.0065 \\
(0.61)\end{array}$ & & & $\begin{array}{l}0.010 \\
(0.49)\end{array}$ \\
\hline Quality $_{f, t}$ & & & $\begin{array}{l}0.0051 \\
(0.75)\end{array}$ & & & $\begin{array}{l}0.0048 \\
(0.72)\end{array}$ & & & $\begin{array}{l}0.029 \\
(1.18)\end{array}$ \\
\hline Recession & & & $\begin{array}{l}-14.5 \\
(-0.44)\end{array}$ & & & $\begin{array}{c}22.1 \\
(0.64)\end{array}$ & & & $\begin{array}{c}-6.45 \\
(-0.09)\end{array}$ \\
\hline Qtr FE & Yes & Yes & Yes & Yes & Yes & Yes & Yes & Yes & Yes \\
\hline Year FE & Yes & Yes & Yes & Yes & Yes & Yes & Yes & Yes & Yes \\
\hline Fund FE & Yes & Yes & Yes & Yes & Yes & Yes & Yes & Yes & Yes \\
\hline YM Cluster & Yes & Yes & Yes & Yes & Yes & Yes & Yes & Yes & Yes \\
\hline Fund Cluster & Yes & Yes & Yes & Yes & Yes & Yes & Yes & Yes & Yes \\
\hline Observations & 85560 & 85560 & 74609 & 85560 & 85560 & 74609 & 85560 & 85560 & 74609 \\
\hline$R^{2}$ & 0.0016 & 0.0022 & 0.0023 & 0.0034 & 0.0036 & 0.0037 & & & \\
\hline
\end{tabular}

$t$ statistics in parentheses 
Table 5: First Stage, OLS, Reduced Form, and Instrumental Variable Time-Series Regressions of the Return on a Zero-Cost Portfolio, Aggregate Fund's Behaviour, and Other Control Variables.

This table uses monthly data from Morningstar from January 1998 through December 2013 (192 observations) to examine the relationship between market liquidity premium and mutual fund active liquidity management. All the variables (excluding Recession) are z-scored. Column 1 and 2 show reduced form regression of aggregate fund performance and flows on realized market volatility. Columns $3-5$ show the coefficients from the 2SLS first stage regression of aggregate fund active liquidity management $B_{f, t}$ on market uncertainty. Columns $6-8$ show the coefficients from OLS regression of return spread between illiquid and liquid stocks on funds' aggregate behaviour $B_{f, t}$. Columns $9-11$ report the reduced for regressions, where the return spread is regressed on realized market volatility. Columns 12-14 show instrumental variable regression coefficients. I use Garman and Klass (1980) realized market volatility $R \mathrm{Vol}_{t}$ as the instrument for the aggregate fund behaviour in the columns 12-14. I include control variables as: return on S\&P500 index $R_{M, t}$, measure of the market-wide liquidity $\Delta N_{\text {oise }}$, Pástor and Stambaugh (2003) measure of equity market liquidity $P S L i q_{t}$, a measure of funding liquidity TEDSpread ${ }_{t}$, funds' aggregated quality measure of their holdings Quality ${ }_{t}$, and a dummy variable Recession is a dummy variable equal one if there was a NBER recession in a given month, otherwise zero. I control for year and quarter fixed effects. The t-statistics reported in the tables reflect robust standard errors.

\begin{tabular}{|c|c|c|c|c|c|c|c|c|c|c|c|c|c|c|}
\hline & \multirow{2}{*}{$\begin{array}{c}\operatorname{Per} f_{t} \\
(1)\end{array}$} & \multirow{2}{*}{$\frac{\text { Flow }_{t}}{(2)}$} & \multicolumn{3}{|c|}{ First Stage } & \multicolumn{3}{|c|}{ OLS } & \multicolumn{3}{|c|}{ Reduced Form } & \multicolumn{3}{|c|}{ IV } \\
\hline & & & (3) & (4) & (5) & (6) & (7) & (8) & (9) & $(10)$ & (11) & $(12)$ & (13) & $(14)$ \\
\hline$B_{t}$ & & & & & & $\begin{array}{c}0.55 \\
(6.47)\end{array}$ & $\begin{array}{c}0.58 \\
(6.15)\end{array}$ & $\begin{array}{c}0.58 \\
(6.25)\end{array}$ & & & & $\begin{array}{c}0.53 \\
(3.64)\end{array}$ & $\begin{array}{c}0.63 \\
(4.42)\end{array}$ & $\begin{array}{c}0.66 \\
(4.37)\end{array}$ \\
\hline$R V o l_{t}$ & $\begin{array}{l}-0.056 \\
(-2.15)\end{array}$ & $\begin{array}{l}-0.40 \\
(-3.38)\end{array}$ & $\begin{array}{c}-0.56 \\
(-4.63)\end{array}$ & $\begin{array}{c}-0.60 \\
(-4.15)\end{array}$ & $\begin{array}{c}-0.62 \\
(-3.99)\end{array}$ & & & & $\begin{array}{c}-0.30 \\
(-3.21)\end{array}$ & $\begin{array}{c}-0.38 \\
(-3.34)\end{array}$ & $\begin{array}{l}-0.40 \\
(-3.34)\end{array}$ & & & \\
\hline$R_{M, t}$ & $\begin{array}{c}0.96 \\
(35.56)\end{array}$ & $\begin{array}{l}0.074 \\
(0.93)\end{array}$ & & $\begin{array}{l}-0.097 \\
(-0.87)\end{array}$ & $\begin{array}{l}-0.096 \\
(-0.85)\end{array}$ & & $\begin{array}{c}-0.14 \\
(-1.52)\end{array}$ & $\begin{array}{c}-0.14 \\
(-1.47)\end{array}$ & & $\begin{array}{l}-0.21 \\
(-2.04)\end{array}$ & $\begin{array}{c}-0.21 \\
(-1.95)\end{array}$ & & $\begin{array}{c}-0.15 \\
(-1.63)\end{array}$ & $\begin{array}{c}-0.14 \\
(-1.58)\end{array}$ \\
\hline$\Delta$ Noise $_{t}$ & $\begin{array}{l}-0.027 \\
(-1.31)\end{array}$ & $\begin{array}{c}0.18 \\
(2.62)\end{array}$ & & $\begin{array}{c}-0.12 \\
(-1.03)\end{array}$ & $\begin{array}{l}-0.14 \\
(-1.10)\end{array}$ & & $\begin{array}{l}0.082 \\
(1.24)\end{array}$ & $\begin{array}{l}0.064 \\
(0.93)\end{array}$ & & $\begin{array}{l}0.014 \\
(0.13)\end{array}$ & $\begin{array}{l}-0.015 \\
(-0.14)\end{array}$ & & $\begin{array}{l}0.091 \\
(1.43)\end{array}$ & $\begin{array}{l}0.076 \\
(1.12)\end{array}$ \\
\hline PSLiq & $\begin{array}{c}0.000088 \\
(0.00)\end{array}$ & $\begin{array}{l}0.020 \\
(0.22)\end{array}$ & & $\begin{array}{l}-0.059 \\
(-0.57)\end{array}$ & $\begin{array}{l}-0.073 \\
(-0.68)\end{array}$ & & $\begin{array}{l}0.075 \\
(0.97)\end{array}$ & $\begin{array}{l}0.084 \\
(1.03)\end{array}$ & & $\begin{array}{l}0.034 \\
(0.38)\end{array}$ & $\begin{array}{l}0.033 \\
(0.35)\end{array}$ & & $\begin{array}{l}0.071 \\
(0.95)\end{array}$ & $\begin{array}{l}0.081 \\
(1.04)\end{array}$ \\
\hline TEDSpread $_{t}$ & $\begin{array}{c}-0.0056 \\
(-0.23)\end{array}$ & $\begin{array}{l}0.016 \\
(0.17)\end{array}$ & & & $\begin{array}{l}0.070 \\
(0.63)\end{array}$ & & & $\begin{array}{l}0.067 \\
(0.93)\end{array}$ & & & $\begin{array}{c}0.13 \\
(1.16)\end{array}$ & & & $\begin{array}{l}0.080 \\
(1.22)\end{array}$ \\
\hline Qualityt $_{t}$ & $\begin{array}{l}0.026 \\
(0.86)\end{array}$ & $\begin{array}{c}0.19 \\
(0.98)\end{array}$ & & & $\begin{array}{l}-0.30 \\
(-1.55)\end{array}$ & & & $\begin{array}{c}0.13 \\
(0.95)\end{array}$ & & & $\begin{array}{l}-0.047 \\
(-0.35)\end{array}$ & & & $\begin{array}{c}0.15 \\
(1.05)\end{array}$ \\
\hline Recession & $\begin{array}{c}68.3 \\
(0.80)\end{array}$ & $\begin{array}{l}183.3 \\
(0.53)\end{array}$ & & & $\begin{array}{l}-28.1 \\
(-0.08)\end{array}$ & & & $\begin{array}{l}-205.9 \\
(-0.67)\end{array}$ & & & $\begin{array}{l}-193.4 \\
(-0.46)\end{array}$ & & & $\begin{array}{l}-174.9 \\
(-0.62)\end{array}$ \\
\hline
\end{tabular}




\begin{tabular}{lcccccccccccccccc}
$\begin{array}{l}\text { Qtr FE } \\
\text { Year FE }\end{array}$ & Yes & Yes & Yes & Yes & Yes & Yes & Yes & Yes & Yes & Yes & Yes & Yes & Yes & Yes \\
Observations & 179 & 179 & 192 & 192 & 179 & 192 & 192 & 179 & 192 & 192 & 179 & 192 & 192 & 179 \\
$R^{2}$ & 0.97 & 0.38 & 0.34 & 0.35 & 0.38 & 0.40 & 0.43 & 0.45 & 0.20 & 0.23 & 0.24 & \\
\hline
\end{tabular}

$t$ statistics in parentheses 
Table 6: First Stage, Reduced Form, and Instrumental Variable Panel Regressions of Fund's Active Liquidity Management on Fund Specific Uncertainty and Illiquidity Shock.

This table uses monthly data from Morningstar from January 2002 through December 2013 (79,424 fundmonth observations) - columns 1 to 6 and from January 1998 through December 2013 (85,560 fund-month observations) - columns 7 and 8, to examine the heterogeneous responses of mutual fund to market uncertainty. All the variables (excluding Recession) are z-scored. Columns 1 to 6 show the results of a direct analysis of mutual fund heterogeneous responses to market uncertainty. Columns 7 and 8 report estimates from indirect approach. Columns 1 and 2 show OLS regression of fund active liquidity management on market-wide and fund-specific uncertainty measure, respectively. I construct fund-specific uncertainty by value weighting S\&P500 sector realized volatilities, where weights are equal to fraction of the portfolio invested in a given sector. In columns 3 and 4 , I regress fund active liquidity management on alternative measures of fund-specific uncertainty, which does not require actual portfolio weights. In column 3, I use weights that correspond to the average of fund-specific sector weights over previous three months. In column 4, I calculate a simple average of the sector-specific realized volatilities. Columns 5-6 report IV regression estimates of fund active liquidity management on the instrumented fund-specific uncertainty measure, where alternative measures from column 3 and 4 are used as instruments. Columns 7-8 show the coefficients from OLS regression of fund behaviour on market-wide uncertainty and fund-specific liquidity shock. The liquidity shock at the fund level is defined in equation 12. I use Garman and Klass (1980) realized volatility estimator as a measure of market and sector uncertainty. I include control variables as: return on S\&P500 index $R_{M, t}$, Hu et al. (2013) measure of the market-wide liquidity $\Delta$ Noise $_{t}$, Pástor and Stambaugh (2003) measure of equity market liquidity $P S L i q_{t}$, a measure of funding liquidity TEDSpread $_{t}$, and a dummy variable Recession is a dummy variable equal one if there was a NBER recession in a given month, otherwise zero. I control for fund, year and quarter fixed effects. The t-statistics reported in the tables reflect robust standard errors that are clustered both at year-month and a fund level.

\begin{tabular}{|c|c|c|c|c|c|c|c|c|}
\hline & \multicolumn{6}{|c|}{ D I R E C T } & \multirow{2}{*}{\multicolumn{2}{|c|}{$\begin{array}{l}\text { I N D I R E C T } \\
\text { Liquidity Shock }\end{array}$}} \\
\hline & \multirow{2}{*}{$\frac{R V \text { ol }_{t}}{(1)}$} & \multirow{2}{*}{$\frac{R V \operatorname{ol}_{f, t}}{(2)}$} & \multicolumn{2}{|c|}{ Reduced Form } & \multicolumn{2}{|c|}{ IV } & & \\
\hline & & & $(3)$ & $(4)$ & $(5)$ & $(6)$ & $(7)$ & $(8)$ \\
\hline$R V \mathrm{ol}_{t}$ & $\begin{array}{l}-0.061 \\
(-3.57)\end{array}$ & & & & & & $\begin{array}{l}-0.045 \\
(-2.49)\end{array}$ & $\begin{array}{l}-0.030 \\
(-1.31)\end{array}$ \\
\hline$R V \operatorname{ol}_{f, t}$ & & $\begin{array}{l}-0.071 \\
(-3.38)\end{array}$ & & & $\begin{array}{l}-0.071 \\
(-3.48)\end{array}$ & $\begin{array}{l}-0.074 \\
(-3.61)\end{array}$ & & \\
\hline$R V o l_{f, t}^{E X}$ & & & $\begin{array}{l}-0.071 \\
(-3.47)\end{array}$ & $\begin{array}{l}-0.072 \\
(-3.59)\end{array}$ & & & & \\
\hline IlliqShock $_{f, t}$ & & & & & & & $\begin{array}{l}-0.029 \\
(-2.84)\end{array}$ & $\begin{array}{l}-0.015 \\
(-1.44)\end{array}$ \\
\hline IlliqShock $_{f, t} \times R \operatorname{Rol}_{t}$ & & & & & & & & $\begin{array}{c}-0.0072 \\
(-2.22)\end{array}$ \\
\hline$R_{M, t}$ & $\begin{array}{c}0.0038 \\
(0.38)\end{array}$ & $\begin{array}{c}0.0049 \\
(0.49)\end{array}$ & $\begin{array}{c}0.0043 \\
(0.43)\end{array}$ & $\begin{array}{c}0.0044 \\
(0.43)\end{array}$ & $\begin{array}{c}0.0049 \\
(0.48)\end{array}$ & $\begin{array}{c}0.0043 \\
(0.43)\end{array}$ & $\begin{array}{c}-0.0045 \\
(-0.45)\end{array}$ & $\begin{array}{c}-0.0029 \\
(-0.28)\end{array}$ \\
\hline$\Delta$ Noise $_{t}$ & $\begin{array}{c}-0.0080 \\
(-0.58)\end{array}$ & $\begin{array}{c}-0.0068 \\
(-0.48)\end{array}$ & $\begin{array}{c}-0.0070 \\
(-0.50)\end{array}$ & $\begin{array}{c}-0.0060 \\
(-0.42)\end{array}$ & $\begin{array}{c}-0.0068 \\
(-0.48)\end{array}$ & $\begin{array}{c}-0.0067 \\
(-0.48)\end{array}$ & $\begin{array}{c}-0.0038 \\
(-0.30)\end{array}$ & $\begin{array}{c}0.0051 \\
(0.37)\end{array}$ \\
\hline$P S L i q_{t}$ & $\begin{array}{l}-0.013 \\
(-1.03)\end{array}$ & $\begin{array}{l}-0.014 \\
(-1.06)\end{array}$ & $\begin{array}{l}-0.014 \\
(-1.06)\end{array}$ & $\begin{array}{l}-0.014 \\
(-1.07)\end{array}$ & $\begin{array}{l}-0.014 \\
(-1.07)\end{array}$ & $\begin{array}{l}-0.015 \\
(-1.11)\end{array}$ & $\begin{array}{l}-0.012 \\
(-1.01)\end{array}$ & $\begin{array}{l}-0.012 \\
(-0.92)\end{array}$ \\
\hline
\end{tabular}




\begin{tabular}{lcccccccc} 
TEDSpread & 0.0037 & 0.0021 & 0.0023 & 0.0022 & 0.0022 & 0.0028 & -0.0015 & -0.0027 \\
& $(0.35)$ & $(0.19)$ & $(0.20)$ & $(0.21)$ & $(0.19)$ & $(0.25)$ & $(-0.24)$ & $(-0.24)$ \\
Recession & 46.3 & 67.6 & 67.5 & 67.6 & 67.8 & 69.7 & 3.59 & 4.07 \\
\multirow{2}{*}{ Qtr FE } & $(1.14)$ & $(1.56)$ & $(1.57)$ & $(1.57)$ & $(1.59)$ & $(1.63)$ & $(0.11)$ & $(0.12)$ \\
Year FE & Yes & Yes & Yes & Yes & Yes & Yes & Yes & Yes \\
Fund FE & Yes & Yes & Yes & Yes & Yes & Yes & Yes & Yes \\
YM Cluster & Yes & Yes & Yes & Yes & Yes & Yes & Yes & Yes \\
Fund Cluster & Yes & Yes & Yes & Yes & Yes & Yes & Yes & Yes \\
\hline Observations & Yes & Yes & Yes & Yes & Yes & Yes & Yes & Yes \\
$R^{2}$ & 79424 & 79424 & 79424 & 79424 & 79424 & 79424 & 85560 & 85560 \\
\hline
\end{tabular}

$t$ statistics in parentheses 
Table 7: OLS, Reduced Form, and Instrumental Variable Panel Regressions of Cash Holdings on Fund Flows and Other Control Variables.

This table uses monthly data from Morningstar from January 1998 through December 2013 (85,560 fund-month observations) to examine the relationship between fund's cash holdings and its net flows. Cash holdings Cash $_{f, t}$ is defined as percentage of TNA held in the for of cash. $B C_{f, t}$ is the active liquidity management measure that incorporates cash holdings and assign the lowest value (zero) of square-root Amihud measure. All the variables (excluding Recession) are z-scored. Columns 1-2 and 3-4 show the OLS coefficients of cash holdings Cash $_{f, t}$ and active liquidity management measure incorporating cash $B C_{f, t}$ on fund's net flows. Columns 5-8 show the coefficients from the reduced form regression of fund's cash holdings $\operatorname{Cash}_{f, t}$ and behaviour including cash $B C_{f, t}$ on realized market volatility $R V V_{t}$. Columns 9-12 show instrumental variable regression coefficients, where I instrument fund's net flows with market uncertainty measure. I use Garman and Klass (1980) realized market volatility $R V l_{t}$ as the instrument for the performance in the columns (7)-(9). I include control variables as: return on S\&P500 index $R_{M, t}$, Hu et al. (2013) measure of the market-wide liquidity $\Delta$ Noise $_{t}$, Pástor and Stambaugh (2003) measure of equity market liquidity $P S L i q_{t}$, a measure of funding liquidity TEDSpread ${ }_{t}$, fund's value-weighted quality measure of its holdings Quality $_{f, t}$, and a dummy variable Recession is a dummy variable equal one if there was a NBER recession in a given month, otherwise zero. I control for fund, year and quarter fixed effects. The t-statistics reported in the tables reflect robust standard errors that are clustered both at year-month and a fund level.

\begin{tabular}{|c|c|c|c|c|c|c|c|c|c|c|c|c|}
\hline & \multicolumn{4}{|c|}{ OLS } & \multicolumn{4}{|c|}{ Reduced Form } & \multicolumn{4}{|c|}{ IV } \\
\hline & \multicolumn{2}{|c|}{$B C_{f, t}$} & \multicolumn{2}{|c|}{$\operatorname{Cash}_{f, t}$} & \multicolumn{2}{|c|}{$B C_{f, t}$} & \multicolumn{2}{|c|}{$\operatorname{Cash}_{f, t}$} & \multicolumn{2}{|c|}{$B C_{f, t}$} & \multicolumn{2}{|c|}{$\operatorname{Cash}_{f, t}$} \\
\hline & (1) & $(2)$ & (3) & (4) & (5) & (6) & (7) & (8) & (9) & $(10)$ & (11) & $(12)$ \\
\hline Flow $_{f, t}$ & $\begin{array}{l}-0.016 \\
(-4.36)\end{array}$ & $\begin{array}{l}-0.016 \\
(-4.23)\end{array}$ & $\begin{array}{c}0.13 \\
(7.75)\end{array}$ & $\begin{array}{c}0.12 \\
(7.35)\end{array}$ & & & & & $\begin{array}{c}1.27 \\
(3.73)\end{array}$ & $\begin{array}{c}2.16 \\
(2.88)\end{array}$ & $\begin{array}{c}-0.92 \\
(-4.13)\end{array}$ & $\begin{array}{l}-1.18 \\
(-2.30)\end{array}$ \\
\hline$R V o l_{t}$ & & & & & $\begin{array}{c}-6.74 \\
(-4.73)\end{array}$ & $\begin{array}{l}-7.33 \\
(-3.67)\end{array}$ & $\begin{array}{c}4.72 \\
(5.11)\end{array}$ & $\begin{array}{c}3.84 \\
(4.05)\end{array}$ & & & & \\
\hline$R_{M, t}$ & & $\begin{array}{l}0.017 \\
(1.60)\end{array}$ & & $\begin{array}{c}-0.0088 \\
(-1.72)\end{array}$ & & $\begin{array}{c}0.00013 \\
(0.01)\end{array}$ & & $\begin{array}{c}0.0031 \\
(0.64)\end{array}$ & & $\begin{array}{l}-0.045 \\
(-1.61)\end{array}$ & & $\begin{array}{l}0.027 \\
(1.61)\end{array}$ \\
\hline$\Delta$ Noise $_{t}$ & & $\begin{array}{l}-0.011 \\
(-0.81)\end{array}$ & & $\begin{array}{c}-0.0061 \\
(-0.86)\end{array}$ & & $\begin{array}{l}-0.012 \\
(-0.87)\end{array}$ & & $\begin{array}{c}-0.0049 \\
(-0.95)\end{array}$ & & $\begin{array}{l}-0.030 \\
(-1.94)\end{array}$ & & $\begin{array}{c}0.0048 \\
(0.40)\end{array}$ \\
\hline$P S \operatorname{Liq}_{t}$ & & $\begin{array}{c}0.0023 \\
(0.17)\end{array}$ & & $\begin{array}{c}-0.0076 \\
(-1.23)\end{array}$ & & $\begin{array}{c}-0.0085 \\
(-0.71)\end{array}$ & & $\begin{array}{c}0.00017 \\
(0.03)\end{array}$ & & $\begin{array}{l}-0.038 \\
(-1.81)\end{array}$ & & $\begin{array}{l}0.016 \\
(1.24)\end{array}$ \\
\hline TEDSpread $_{t}$ & & $\begin{array}{l}-0.015 \\
(-0.85)\end{array}$ & & $\begin{array}{l}0.027 \\
(2.40)\end{array}$ & & $\begin{array}{c}0.0065 \\
(0.62)\end{array}$ & & $\begin{array}{l}0.015 \\
(1.32)\end{array}$ & & $\begin{array}{c}0.0059 \\
(0.29)\end{array}$ & & $\begin{array}{l}0.017 \\
(1.19)\end{array}$ \\
\hline Quality $_{f, t}$ & & $\begin{array}{l}-0.011 \\
(-1.04)\end{array}$ & & $\begin{array}{l}-0.020 \\
(-0.97)\end{array}$ & & $\begin{array}{l}-0.012 \\
(-1.14)\end{array}$ & & $\begin{array}{l}-0.021 \\
(-1.01)\end{array}$ & & $\begin{array}{l}0.017 \\
(0.44)\end{array}$ & & $\begin{array}{l}-0.037 \\
(-1.19)\end{array}$ \\
\hline
\end{tabular}




\begin{tabular}{|c|c|c|c|c|c|c|c|c|c|c|c|c|}
\hline Recession & & $\begin{array}{l}-17.9 \\
(-0.55)\end{array}$ & & $\begin{array}{c}66.1 \\
(1.65)\end{array}$ & & $\begin{array}{c}17.3 \\
(0.51)\end{array}$ & & $\begin{array}{c}46.7 \\
(1.26)\end{array}$ & & $\begin{array}{c}-3.31 \\
(-0.05)\end{array}$ & & $\begin{array}{c}54.5 \\
(0.98)\end{array}$ \\
\hline Qtr FE & Yes & Yes & Yes & Yes & Yes & Yes & Yes & Yes & Yes & Yes & Yes & Yes \\
\hline Year FE & Yes & Yes & Yes & Yes & Yes & Yes & Yes & Yes & Yes & Yes & Yes & Yes \\
\hline Fund FE & Yes & Yes & Yes & Yes & Yes & Yes & Yes & Yes & Yes & Yes & Yes & Yes \\
\hline YM Cluster & Yes & Yes & Yes & Yes & Yes & Yes & Yes & Yes & Yes & Yes & Yes & Yes \\
\hline Fund Cluster & Yes & Yes & Yes & Yes & Yes & Yes & Yes & Yes & Yes & Yes & Yes & Yes \\
\hline Observations & 85560 & 74609 & 84634 & 73691 & 85560 & 74609 & 84634 & 73691 & 85560 & 74609 & 84634 & 73691 \\
\hline$R^{2}$ & 0.014 & 0.014 & 0.46 & 0.46 & 0.015 & 0.015 & 0.44 & 0.45 & & & & \\
\hline
\end{tabular}

$t$ statistics in parentheses 
Table 8: Reduced Form, and IV Panel Regressions with Alternative Measures of Liquidity.

This table uses monthly data from Morningstar from January 1998 through December 2013 (85,560 fund-month observations) to examine the relationship between fund's active asset allocation and its net flows. $\ln (A m i h u d)$ is a natural logarithm of Amihud measure. Bid-Ask is a proportional Bis-Ask spread. All the variables (excluding Recession) are z-scored. Columns 1-4 show the reduced form regression coefficient of alternative behaviour measures on fund's net flows. Columns 5-8 show the coefficients from the 2SLS second stage regression of fund's active liquidity management (computed with alternative liquidity measures) on fund flows instrumented with realized market volatility $R$ Vol $_{t}$. I use Garman and Klass (1980) realized market volatility $R V$ I $_{t}$ as the instrument for the performance in the columns (7)-(9). I include control variables as: return on S\&P500 index $R_{M, t}$, Hu et al. (2013) measure of the market-wide liquidity $\Delta$ Noise $_{t}$, Pástor and Stambaugh (2003) measure of equity market liquidity PSLiq $q_{t}$, a measure of funding liquidity TEDSpread ${ }_{t}$, fund's value-weighted quality measure of its holdings Quality f $_{f, t}$, and a dummy variable Recession is a dummy variable equal one if there was a NBER recession in a given month, otherwise zero. I control for fund, year and quarter fixed effects. The t-statistics reported in the tables reflect robust standard errors that are clustered both at year-month and a fund level.

\begin{tabular}{|c|c|c|c|c|c|c|c|c|}
\hline & \multicolumn{4}{|c|}{ Reduced Form } & \multicolumn{4}{|c|}{ IV } \\
\hline & \multicolumn{2}{|c|}{$\ln ($ Amihud $)$} & \multicolumn{2}{|c|}{$B i d-A s k$} & \multicolumn{2}{|c|}{$\ln ($ Amihud $)$} & \multicolumn{2}{|c|}{$B i d-A s k$} \\
\hline & (1) & $(2)$ & (3) & (4) & (5) & (6) & (7) & (8) \\
\hline Flow $_{f, t}$ & & & & & $\begin{array}{c}3.09 \\
(4.05)\end{array}$ & $\begin{array}{c}4.52 \\
(2.63)\end{array}$ & $\begin{array}{c}1.45 \\
(3.92)\end{array}$ & $\begin{array}{c}2.56 \\
(2.64)\end{array}$ \\
\hline$R V \mathrm{ol}_{t}$ & $\begin{array}{c}-16.4 \\
(-5.80)\end{array}$ & $\begin{array}{c}-15.3 \\
(-4.24)\end{array}$ & $\begin{array}{c}-7.74 \\
(-3.95)\end{array}$ & $\begin{array}{c}-8.70 \\
(-2.90)\end{array}$ & & & & \\
\hline$R_{M, t}$ & & $\begin{array}{l}0.018 \\
(0.73)\end{array}$ & & $\begin{array}{c}0.00044 \\
(0.03)\end{array}$ & & $\begin{array}{l}-0.075 \\
(-1.25)\end{array}$ & & $\begin{array}{l}-0.053 \\
(-1.37)\end{array}$ \\
\hline$\Delta$ Noise $_{t}$ & & $\begin{array}{l}0.016 \\
(0.58)\end{array}$ & & $\begin{array}{c}-0.0079 \\
(-0.48)\end{array}$ & & $\begin{array}{l}-0.021 \\
(-0.51)\end{array}$ & & $\begin{array}{l}-0.029 \\
(-1.42)\end{array}$ \\
\hline$P S L i q_{t}$ & & $\begin{array}{c}-0.0020 \\
(-0.13)\end{array}$ & & $\begin{array}{c}-0.0045 \\
(-0.24)\end{array}$ & & $\begin{array}{l}-0.064 \\
(-1.64)\end{array}$ & & $\begin{array}{l}-0.040 \\
(-1.34)\end{array}$ \\
\hline TEDSpread $_{t}$ & & $\begin{array}{l}-0.021 \\
(-0.94)\end{array}$ & & $\begin{array}{l}0.036 \\
(1.98)\end{array}$ & & $\begin{array}{l}-0.023 \\
(-0.59)\end{array}$ & & $\begin{array}{l}0.035 \\
(1.26)\end{array}$ \\
\hline Quality $_{f, t}$ & & $\begin{array}{l}-0.046 \\
(-2.80)\end{array}$ & & $\begin{array}{l}-0.028 \\
(-1.93)\end{array}$ & & $\begin{array}{l}0.012 \\
(0.16)\end{array}$ & & $\begin{array}{r}0.0052 \\
(0.11)\end{array}$ \\
\hline Recession & & $\begin{array}{c}85.6 \\
(0.88)\end{array}$ & & $\begin{array}{c}-93.8 \\
(-1.28)\end{array}$ & & $\begin{array}{c}42.4 \\
(0.28)\end{array}$ & & $\begin{array}{l}-118.2 \\
(-1.58)\end{array}$ \\
\hline Qtr FE & Yes & Yes & Yes & Yes & Yes & Yes & Yes & Yes \\
\hline Year FE & Yes & Yes & Yes & Yes & Yes & Yes & Yes & Yes \\
\hline Fund FE & Yes & Yes & Yes & Yes & Yes & Yes & Yes & Yes \\
\hline YM Cluster & Yes & Yes & Yes & Yes & Yes & Yes & Yes & Yes \\
\hline Fund Cluster & Yes & Yes & Yes & Yes & Yes & Yes & Yes & Yes \\
\hline Observations & 85560 & 74609 & 85560 & 74609 & 85560 & 74609 & 85560 & 74609 \\
\hline$R^{2}$ & 0.053 & 0.055 & 0.033 & 0.035 & & & & \\
\hline
\end{tabular}

$t$ statistics in parentheses 
Table 9: Reduced Form, and Instrumental Variable Panel and Time-Series Regressions with Non-forecastable Component of Market Volatility.

In this table columns 1-10 use monthly fund-level data from Morningstar from January 1998 through December 2013 (85,560 observations), the columns 11-14 use aggregated fund behaviour (192 observations) to examine the relationship between market liquidity premium and mutual fund active liquidity management. All the variables (excluding Recession) are z-scored. Column 1-2 (3-4) show reduced from panel regression of fund performance (flows) on market volatility shock Res $(\mathrm{Vol})_{t}$. Columns $5-6$ show the coefficients from the 2SLS second stage regression of fund flows on instrumented performance with the non-forecastable component of market uncertainty. Reduced form and instrumental variable regressions of aggregate funds' active liquidity management $B_{t}$ are in columns $7-8$ and $9-10$, respectively. Columns 11-12 and 13-14 show the coefficients from reduced form and 2SLS second stage regressions of return spread between illiquid and liquid stocks on market volatility shock and instrumented funds active liquidity management $B_{t}$. The non-forecastable component of market volatility is a residual from the regression of realized market volatility $R$ Vol $_{t}$ (constructed as in Garman and Klass (1980)) on the current month VIX forecast. I include control variables as: return on S\&P500 index $R_{M, t}$,

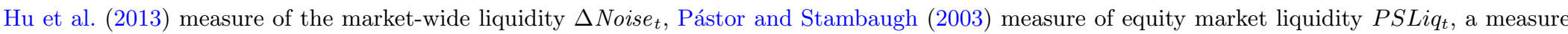
of funding liquidity TEDSpread ${ }_{t}$, funds' aggregated quality measure of their holdings Quality $_{t}$, and a dummy variable Recession is a dummy variable equal one if there was a NBER recession in a given month, otherwise zero. I control for year and quarter fixed effects. The t-statistics reported in the tables reflect robust standard errors.

\begin{tabular}{|c|c|c|c|c|c|c|c|c|c|c|c|c|c|c|}
\hline & \multirow{2}{*}{\multicolumn{2}{|c|}{$\begin{array}{c}P e r f_{t} \\
\text { Reduced }\end{array}$}} & \multirow{2}{*}{\multicolumn{4}{|c|}{ Reduced }} & \multicolumn{4}{|c|}{$B_{t}$} & \multicolumn{4}{|c|}{$L P_{t}$} \\
\hline & & & & & & & \multicolumn{2}{|c|}{ Reduced } & \multicolumn{2}{|c|}{ IV } & \multicolumn{2}{|c|}{ Reduced } & \multicolumn{2}{|c|}{ IV } \\
\hline & (1) & $(2)$ & $(3)$ & $(4)$ & $(5)$ & $(6)$ & $(7)$ & $(8)$ & $(9)$ & $(10)$ & $(11)$ & $(12)$ & $(13)$ & $(14)$ \\
\hline $\operatorname{Res}(\mathrm{Vol})_{t}$ & $\begin{array}{l}-0.20 \\
(-4.85)\end{array}$ & $\begin{array}{c}-0.18 \\
(-3.23)\end{array}$ & $\begin{array}{l}-0.033 \\
(-4.23)\end{array}$ & $\begin{array}{l}-0.023 \\
(-2.51)\end{array}$ & & & $\begin{array}{l}-0.041 \\
(-5.81)\end{array}$ & $\begin{array}{l}-0.043 \\
(-3.66)\end{array}$ & & & $\begin{array}{c}-0.17 \\
(-2.36)\end{array}$ & $\begin{array}{c}-0.30 \\
(-2.86)\end{array}$ & & \\
\hline $\operatorname{Per} f_{f, t}$ & & & & & $\begin{array}{c}0.16 \\
(4.91)\end{array}$ & $\begin{array}{c}0.13 \\
(2.39)\end{array}$ & & & & & & & & \\
\hline Flow $_{f, t}$ & & & & & & & & & $\begin{array}{c}1.26 \\
(4.55)\end{array}$ & $\begin{array}{l}1.89 \\
(2.41)\end{array}$ & & & & \\
\hline$B_{t}$ & & & & & & & & & & & & & $\begin{array}{c}0.39 \\
(2.77)\end{array}$ & $\begin{array}{c}0.61 \\
(3.73)\end{array}$ \\
\hline$R_{M, t}$ & & $\begin{array}{l}0.039 \\
(0.59)\end{array}$ & & $\begin{array}{l}0.019 \\
(2.62)\end{array}$ & & $\begin{array}{l}0.014 \\
(1.03)\end{array}$ & & $\begin{array}{c}-0.000029 \\
(-0.00)\end{array}$ & & $\begin{array}{l}-0.037 \\
(-1.27)\end{array}$ & & $\begin{array}{c}-0.22 \\
(-1.97)\end{array}$ & & $\begin{array}{c}-0.14 \\
(-1.60)\end{array}$ \\
\hline$\Delta$ Noise $_{t}$ & & $\begin{array}{c}0.0088 \\
(0.18)\end{array}$ & & $\begin{array}{l}0.016 \\
(1.96)\end{array}$ & & $\begin{array}{l}0.015 \\
(1.90)\end{array}$ & & $\begin{array}{c}0.0045 \\
(0.33)\end{array}$ & & $\begin{array}{l}-0.027 \\
(-1.88)\end{array}$ & & $\begin{array}{l}0.069 \\
(0.66)\end{array}$ & & $\begin{array}{l}0.069 \\
(0.97)\end{array}$ \\
\hline$P S L i q_{t}$ & & $\begin{array}{c}0.0041 \\
(0.07)\end{array}$ & & $\begin{array}{l}0.014 \\
(1.92)\end{array}$ & & $\begin{array}{l}0.013 \\
(1.50)\end{array}$ & & $\begin{array}{c}-0.0086 \\
(-0.61)\end{array}$ & & $\begin{array}{l}-0.035 \\
(-1.63)\end{array}$ & & $\begin{array}{l}0.050 \\
(0.52)\end{array}$ & & $\begin{array}{l}0.083 \\
(1.07)\end{array}$ \\
\hline
\end{tabular}




\begin{tabular}{|c|c|c|c|c|c|c|c|c|c|c|c|c|c|c|}
\hline TEDSpread & & $\begin{array}{c}-0.0096 \\
(-0.21)\end{array}$ & & $\begin{array}{c}-0.0067 \\
(-0.84)\end{array}$ & & $\begin{array}{c}-0.0055 \\
(-0.65)\end{array}$ & & $\begin{array}{l}-0.010 \\
(-0.65)\end{array}$ & & $\begin{array}{r}0.0027 \\
(0.14)\end{array}$ & & $\begin{array}{l}0.030 \\
(0.26)\end{array}$ & & $\begin{array}{l}0.072 \\
(1.08)\end{array}$ \\
\hline Quality $_{f, t}$ & & $\begin{array}{l}0.055 \\
(1.75)\end{array}$ & & $\begin{array}{l}-0.013 \\
(-0.80)\end{array}$ & & $\begin{array}{l}-0.020 \\
(-1.18)\end{array}$ & & $\begin{array}{l}-0.016 \\
(-1.63)\end{array}$ & & $\begin{array}{r}0.0087 \\
(0.26)\end{array}$ & & $\begin{array}{l}-0.061 \\
(-0.45)\end{array}$ & & $\begin{array}{c}0.14 \\
(0.98)\end{array}$ \\
\hline Recession & & $\begin{array}{l}114.6 \\
(0.47)\end{array}$ & & $\begin{array}{c}-2.92 \\
(-0.10)\end{array}$ & & $\begin{array}{l}-17.5 \\
(-0.43)\end{array}$ & & $\begin{array}{c}-10.9 \\
(-0.34)\end{array}$ & & $\begin{array}{c}-5.37 \\
(-0.08)\end{array}$ & & $\begin{array}{l}-380.3 \\
(-0.92)\end{array}$ & & $\begin{array}{l}-194.1 \\
(-0.67)\end{array}$ \\
\hline Qtr FE & Yes & Yes & Yes & Yes & Yes & Yes & Yes & Yes & Yes & Yes & Yes & Yes & Yes & Yes \\
\hline Year FE & Yes & Yes & Yes & Yes & Yes & Yes & Yes & Yes & Yes & Yes & Yes & Yes & Yes & Yes \\
\hline Fund FE & Yes & Yes & Yes & Yes & Yes & Yes & Yes & Yes & Yes & Yes & No & No & No & No \\
\hline YM Cluster & Yes & Yes & Yes & Yes & Yes & Yes & Yes & Yes & Yes & Yes & No & No & No & No \\
\hline Fund Cluster & Yes & Yes & Yes & Yes & Yes & Yes & Yes & Yes & Yes & Yes & No & No & No & No \\
\hline Observations & 85560 & 74609 & 85560 & 74609 & 85560 & 74609 & 85560 & 74609 & 85560 & 74609 & 192 & 179 & 192 & 179 \\
\hline$R^{2}$ & 0.075 & 0.082 & 0.16 & 0.17 & & & 0.014 & 0.014 & & & 0.17 & 0.22 & & \\
\hline
\end{tabular}

